\title{
Water column nutrients and sedimentary denitrification in the Gulf of Maine
}

\author{
JOHN P. CHRISTENSEN, ${ }^{*}$ DAVID W. TOWNSEND $\dagger$ and \\ JOSEPH P. MONTOYA
}

(Received 22 February 1994; accepted 6 September 1994)

\begin{abstract}
Sedimentary denitrification acts to remove nitrogen from both the sediments and water column in continental shelf ecosystems, so that in enclosed shelf areas where water residence times are long (about a year in the Gulf of Maine), significant rates of sedimentary denitrification might lower inorganic nitrogen concentrations. We examined this using a basin-wide suite of hydrographic and nutrient data collected in mid-summer. Total inorganic nitrogen (TIN) concentrations (nitrate + nitrite + ammonium) were highest in the aged North Atlantic continental slope waters found at depth in the Jordan Basin on the eastern side of the Gulf. Phosphate and silicate concentrations were moderately high in these waters. On the western side of the Gulf, Wilkinson Basin receives much less of the nutrient-rich slope waters. In these deep waters, 'IIN concentrations were lower and phosphate and silicate concentrations higher than in the Jordan Basin. In the intermediate and deep waters, TIN/PO $\mathrm{PO}_{4}$ ratios averaged 19 on the eastern side but only $15-16$ on the western side of the Gulf. Partially isolated regions within the Gulf had even lower TIN/PO ratios. The differences in this ratio suggested the occurrence of either a non-stoichiometric reduction in nitrogen or an enrichment in phosphate between the eastern and western sides of the Gulf. The relationship between phosphate and silicate was identical in open waters on both sides of the Gulf, indicating that the difference in the TIN/PO ratio was due to a loss of nitrogen. A parameter, delta- $\mathrm{N}$, quantified the non-stoichiometric nitrogen loss and was defined as, $\Delta \mathrm{N}=$ $\alpha\left[\mathrm{PO}_{4}\right]-[\mathrm{TIN}]$, where $\left[\mathrm{PO}_{4}\right]$ and $[\mathrm{TIN}]$ were the measured concentrations in an individual water sample and $\alpha$ was the average TIN/PO ratio in the Jordan Basin. Within and below the Maine Intermediate Waters $(50-120 \mathrm{~m})$, the distribution of $\Delta \mathrm{N}$ showed the removal of $2-4 \mu$ gat $\mathrm{N}^{-1}$ in most of the waters west and south-west of the Jordan Basin. $\Delta \mathrm{N}$ was greater in waters close to the sediments suggesting that sediments were the site of nitrogen removal. The overall rate of denitrification was estimated to be $31.2-46.8 \times 10^{\circ}$ gat $\mathrm{N} \mathrm{y}^{-1}$ based on the average $\Delta \mathrm{N}$, the water volume within the Gulf and the water residence time. When normalized to sediment area, this rate was $0.80-1.21 \mathrm{pgat} \mathrm{N} \mathrm{cm}^{-2} \mathrm{~s}^{-1}$. The classical inorganic nitrogen budget of the Gulf of Maine, based on inflow rates and nutrient concentrations of the source waters, was reassessed and found to be unbalanced by $43.1 \times 10^{6}$ gat $\mathrm{N} \mathrm{y}^{-1}$ with $\mathrm{TIN}$ inputs $\left(138.6 \times 10^{9}\right.$ gat $\left.\mathrm{N} \mathrm{y}^{1}\right)$ exceeding advective TIN losses $\left(-95.5 \times 10^{9}\right.$ gat $\left.\mathrm{N} \mathrm{y}^{-1}\right)$. Organic matter burial and net organic nitrogen export at the rate of $1.5 \%$ of the primary productivity could account for $23 \%$ of the imbalance $\left(-10.0 \times 10^{9}\right.$ gat $\mathrm{N}^{-1}$ ). Denitrification, at the aerial rate of 0.85 pgat $\mathrm{N} \mathrm{cm}^{-2} \mathrm{~s}^{-1}$ accounted for the remainder $\left(-33.1 \times 10^{9}\right.$ gat $\left.\mathrm{N}^{-1}\right)$.
\end{abstract}

\section{INTRODUCTION}

Denitrification is the bacterial oxidation of organic matter using $\mathrm{NO}_{3}^{-}, \mathrm{NO}_{2}^{-}$, or $\mathrm{N}_{2} \mathrm{O}$ as the terminal oxidant rather than $\mathrm{O}_{2}$. With complete denitrification, these oxidants are

${ }^{*}$ Bigelow Laboratory for Ocean Sciences, West Boothbay Harbor, ME 04575, U.S.A.

$\dagger$ Department of Oceanography, University of Maine, Orono, ME 04469, U.S.A.

$\ddagger$ The Biological Laboratories, Harvard University, Cambridge, MA 02138, U.S.A. 


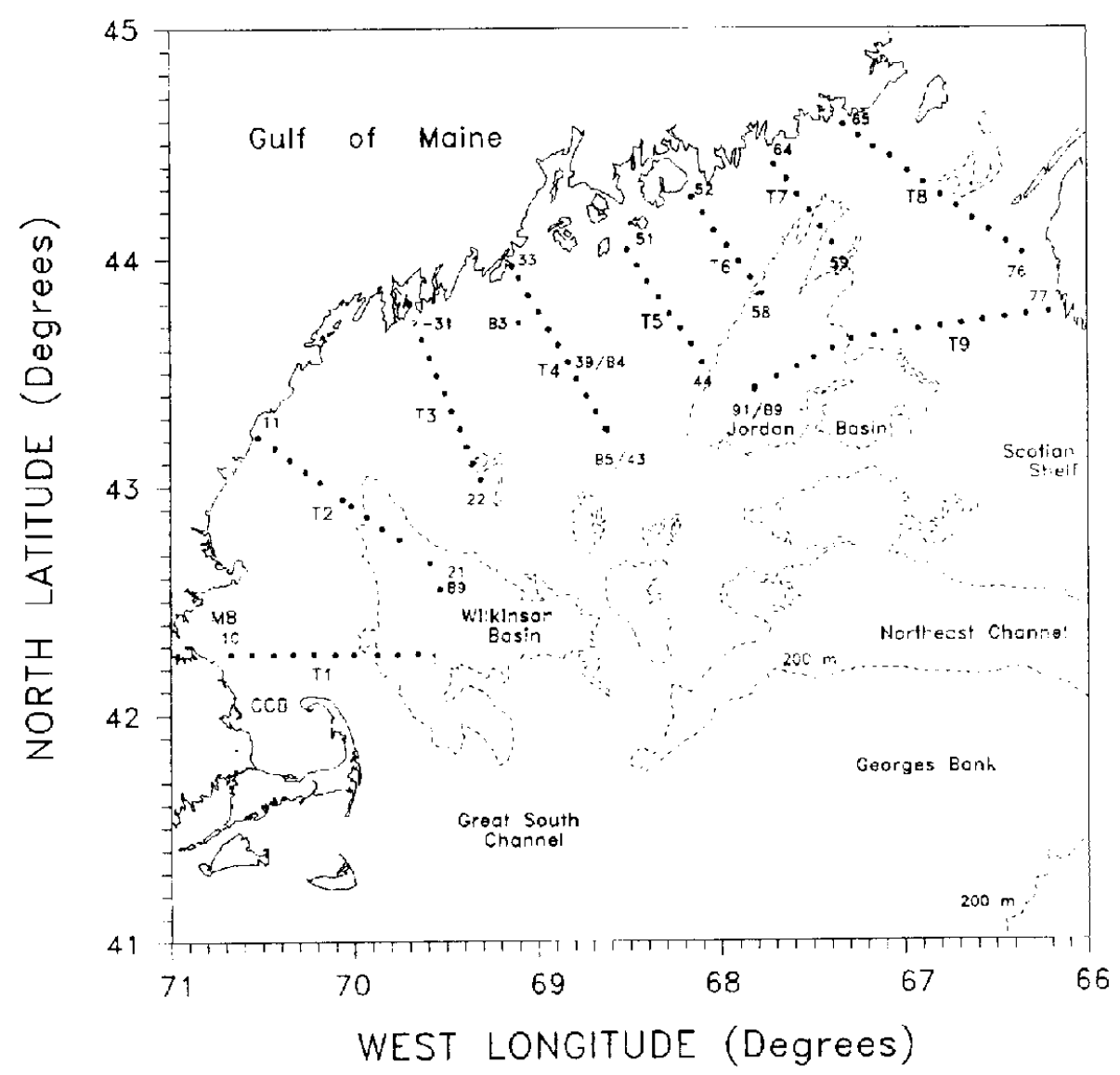

Fig. 1. Stations sampled in summer in the Gull of Maine. Station numbers are in small letters. Transect lines are T1-T9. Massachusetts Bay and Cape Cod Bay are listed as MB and CCB, respectively.

converted to nitrogen gas $\left(\mathrm{N}_{2}\right)$. This anaerobic process is primarily restricted to anoxic water columns and to the anoxic portions of marine sediments. The global denitrification rate in sediments of continental shelves and estuaries conservatively accounts for one-third of all nitrogen losses from the world ocean (Christensen et al., 1987; Codispoti, 1989). Since the process removes available nitrogen from the pore waters and water column, it has been suggested to play an important role in lowering nutrient concentrations and limiting primary production in coastal and continental shelf regions (Smith et al., 1985; Seitzinger, 1988; Kempet al., 1990). This would be especially important in shelf seas where nutrient input rates are low relative to rates of denitrification, such as in the Gulf of Maine, as we show in the following pages.

The Gulf of Maine is a glacially carved, semi-enclosed shelf sea in which several central basins, including the Jordan and Wilkinson Basins, have depths of $300 \mathrm{~m}$ (Fig. 1). The shoreline from Cape Cod to Nova Scotia bounds its western and northern sides. 
Topographic shallow areas of Browns Bank, Georges Bank and Nantucket Shoals on the castern and southern sides act to restrict exchange between the Gulf and the continental slope region. Some water enters the Gulf of Maine from the Scotian Shelf. In addition, nutrient-rich Atlantic slope water enters along the north wall of the narrow $370 \mathrm{~m}$ deep North-east Channel (Ramp et al., 1985), and flows primarily into the deep Jordan Basin (Brooks, 1985; Brooks and Townsend, 1989). Nutrients within this basin are upwelled and entrained in the strong south-west flow of the Eastern Maine coastal current (Townsend $e t$ al., 1987; Brooks and Townsend, 1989). Part of this current may recirculate in onc or more large counter-clockwise gyres centered over Jordan and Wilkinson Basins (Bigelow, 1927; Brooks, 1985, 1987; Butman and Beardsley, 1987). Some of the central waters may exit the Gulf either via a narrow subsurface jet hugging the north side of Georges Bank or by recirculating around Georges Bank and returning to the New England Shelf south of Cape Cod. Alternatively, central waters may exit the Gulf by drifting southward through the Great South Channel east of Cape Cod (Bigelow, 1927; Butman et al., 1982; Brooks and Townsend, 1989). Waters within the Gulf have a long residence time (one year, Hopkins and Garfield, 1979); thus, seasonal changes strongly affect the water masses within the Gulf. Winter convection vertically homogenizes the waters to depths of $130 \mathrm{~m}$ or more and forms the Maine intermediate water which is identified in the warmer months as a temperature minimum between 50 and $120 \mathrm{~m}$ (Hopkins and Garfield, 1979). With spring heating, the formation of a strong thermocline in the offshore waters promotes a significant spring phytoplankton bloom as early as February (Bigelow et al., 1940; Lillick, 1940; Cura, 1987; Townsend et al., 1992). In the central Gulf, this productivity strips nitrogen from the upper $30 \mathrm{~m}$ by May-June. Productivity is moderately high $\left(290 \mathrm{~g} \mathrm{C} \mathrm{m}^{-2}\right.$ $\mathrm{y}^{-1}$ ) for the eastern shelf of the U.S.A. (O'Rcilly and Busch, 1984). Coastal waters are much less stratified in warmer months than the offshore waters because of strong tidal mixing, and thus, euphotic zone waters in some coastal arcas may contain plentiful nutrients throughout the year (Townsend, 1991).

Within the Gulf of Maine, direct measurements of sedimentary denitrification rates have demonstrated moderately high rates, common of most continental shelves (Christensen, in preparation). Coupled with the long water residence time, denitrification might cause a detectable decrease in inorganic nitrogen concentrations within these waters. In this report, we examined this hypothesis based on a basin-wide survey of water column nutrients.

\section{METHODS}

Vertical profiles of temperature, salinity, and nutrients were measured at 96 stations on nine transects in the Gulf of Maine in July 16-24, 1985 (Fig. 1). Data were presented in detail in Townsend and Christensen (1986) and surface distributions were illustrated in Townsend et al. (1987). Temperature and salinity were determined from the sea surface to within $5 \mathrm{~m}$ of the sea floor using a Neil Brown Mark III CTD. The CTD data used here were those measured at the time the rosette-mounted Niskin bottles were closed. Nutrients were measured on-board using a six-channel autoanalyzer. Nitratc, nitrite, ammonium, phosphate and silicate were measured using the methods of Strickland and Parsons (1972). Urea was measured by the method of Aminot and Kerouel (1982). These hydrographic and nutrient data were used to examine the relationships between temperature, salinity and nutrients, and to evaluate their geographical distribution. Geographical 
distributions were determined using optimal interpolation methods (Burgess and Webster, 1980). For this, data were linearly interpolated between measured rosette-bottle samples either to specific sigma- $t$ or depth levels. Spatial autocorrelation was then performed based on least-squares fit of specific semivariogram models to this data. Block kriging over $0.05^{\circ}$ squares (both latitude and longitude) was used to interpolate the data over the entire range of latitude and longitude represented by the data.

\section{RESULTS}

Our mid-summer survey occurred during a time of maximum stratification, which should allow the greatest differentiation of water types. Water temperatures ranged between 4.7 and $18.15^{\circ} \mathrm{C}$, salinities ranged between 30.5 and $34.77 \mathrm{~g} \mathrm{~kg}^{-1}$, and as a result $\sigma$ t values were between 22.39 and $26.96 \mathrm{mg}{ }^{1}$. Hopkins and Garfield (1979) demonstrated the general pattern of $T-S$ relationships in the Gulf of Maine, which included a warm, relatively fresh surface layer, cold moderate-salinity Maine intermediate water which was formed in winter by cooling, convection and mixing of the near-surface and middepth waters, and warmer, salty Maine bottom water traceable to the introduction of North Atlantic slope water through the north-east channel. We observed these same water types throughout the Gulf, although we found considerable variability in the $T-S$ relationships across the Gulf (Fig. 2, top).

We found that waters were stratified over most of the Gulf. Nitrate concentrations in the upper $2 \mathrm{~m}$ were frequently nil and generally less than 0.1 agat $\mathrm{N}{ }^{1}{ }^{1}$. [Surface distributions of nitrate were presented in Townsend et al. (1987).] The highest nitrate concentration (19.4 $\mu$ gat $\mathrm{N}^{-1}$ ) occurred in the bottom waters of the deep Jordan Basin. Nitrite and ammonium concentrations were generally low, with highest observed concentrations being 0.57 and $0.74 \mu$ gat $\mathrm{N}^{-1}$ respectively. Total inorganic nitrogen (TIN) was evaluated as the sum of the nitrate, nitrite and ammonium concentrations in an individual samplc. Lowest TIN concentrations (generally $0.1-0.2 \mu$ gat $\mathrm{N}^{-1}$ ) were found in the stratified surface waters. As nitrate was frequently absent from these samples, these TIN concentrations represent low concentrations of nitrite and ammonium. The highest concentrations of TIN (19.51 $\mu$ gat $\mathrm{N} \mathrm{I}^{1}$ ) were found in the Jordan Basin bottom waters. Throughout the Gulf, urea concentrations generally ranged between 0.2 and $0.4 \mu$ mol urea $1^{-1}$ (each molecule of urea has two atoms of nitrogen). Larger values $\left(>0.5 \mu\right.$ mol urea l ${ }^{-1}$ ) were found sporadically. No obvious change in urea concentration was seen with either depth or geographic location. Because the average ured concentration was greater than TIN concentrations in the stratificd surface waters, urea could be important in recycling of nitrogen within the stratified waters. However, the relative constancy of the urea concentrations may argue instead that this level of urea represents either the natural or analytical background. We accept this latter viewpoint and neglect urea in the following analyses. Phosphate concentrations $\left(\mathrm{PO}_{4}\right)$ were measurable in all samples. Lowest concentrations were found in the highly stratified surface waters. These waters averaged about $0.1 \mu$ gat $\mathrm{P}^{-1}$ but were occasionally as low as $0.02 \mu$ gat $\mathrm{P} \mathrm{I}^{\cdots 1}$. The highest concentration $\left(1.23 \mu\right.$ gat $\mathrm{P}^{1}{ }^{1}$ ) was found in the deep waters of Wilkinson Basin. Dissolved silicate concentrations were also low in the surface waters, averaging $1-2 \mu$ gat Si $\mathrm{I}^{-1}$. The lowest concentration $\left(0.3 \mu \mathrm{gat} \mathrm{Si} \mathrm{l}^{-1}\right)$ was found in western Gulf surface waters. As for phosphate, the highest concentration $\left(27.30 \mu\right.$ gat Si $\left.1^{-1}\right)$ was found in the deep waters of the Wilkinson Basin. Nutrients do not show a simple dependence on salinity 

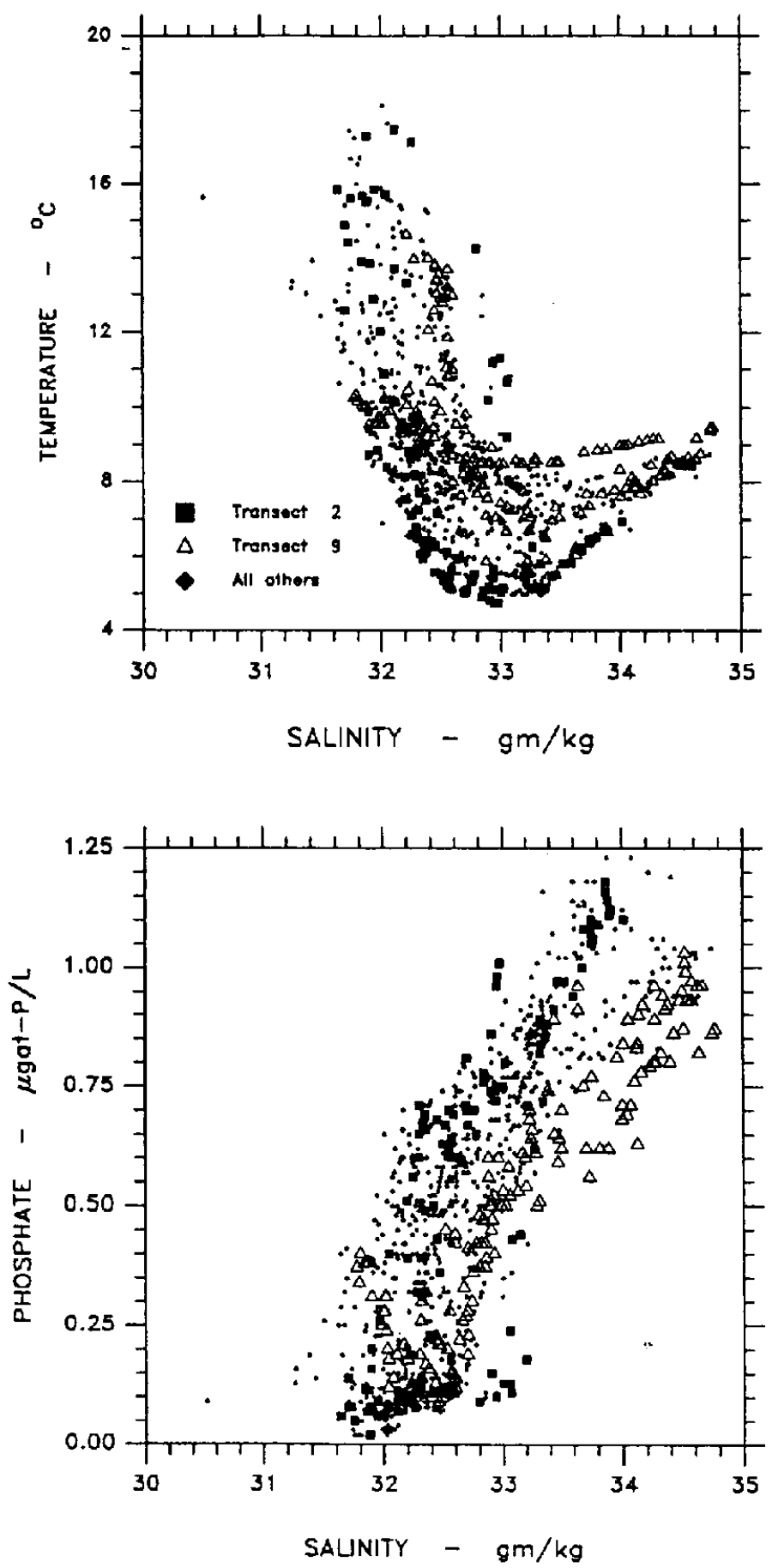

Fig. 2. Top: temperature vs salinity for all samples taken from transect 2 (tilled squares), transect 9 (open triangles) and all other transects (dots), bottom: phosphate vs salinity for transects 2 and 9 and all other transects. Symbols are the same as in the top panel. 
(Fig. 2, bottom; only phosphate is shown), which demonstrates their strongly nonconservative character in this sea. This highly variable relationship with salinity also precludes the use of simple mixing models to investigate nutrient cycling.

Although surface waters showed uniformly low nutrient concentrations across most of the Gulf, we observed that deep waters differed markedly in their nutrient content between eastern and western sides of the Gulf. To show this difference, we emphasize data from two transects (Fig. 1). Transect 9 is from the eastern Gulf of Maine adjacent to Nova Scotia and includes the Jordan Basin. Transect 2 extends from the New Hampshire coast to the central Wilkinson Basin and represents waters on the western side of the Gulf.

Characteristic profiles from Jordan Basin (transect 9) and Wilkinson Basin (transect 2) are presented (Fig. 3). Comparison of the deep waters of the two basins reveals more $\mathrm{NO}_{3}$ in the deep waters of the Jordan Basin but more $\mathrm{PO}_{4}$ in the bottom of the Wilkinson Basin. In the surface waters of the Jordan Basin, $\mathrm{NO}_{3}^{-}$concentrations are unmeasurable and $\mathrm{PO}_{4}$ levels are low. Both nutrients increase in concentration with depth below $20 \mathrm{~m}$, so that average concentrations in the bottom waters of the Jordan Basin were 18-19 $\mu$ gat $\mathrm{N}^{-1}$ and $0.95 \mu$ gat $\mathrm{P} \mathrm{I}^{-1}$. In the surface waters of the Wilkinson Basin, levels of nitrate and phosphate were as low as those in the Jordan Basin. Below $25 \mathrm{~m}$, both increased to high values of $16 \mu$ gat $\mathrm{N}^{-1}$ and $>1.1 \mu$ gat $\mathrm{P} \mathrm{I}^{-1}$ at depth (Fig. 3). The ratio of IIN relative to $\mathrm{PO}_{4}$ was low in the surface waters of both basins, averaging between one and two, and increased quickly with depth to high, constant values. In the Jordan Basin, TIN/PO ${ }_{4}$ ratios averaged 18.77 for depths below $50 \mathrm{~m}$ (standard deviation $=1.10, n=28$, Stas $88-91$ ), whereas in Wilkinson Basin they averaged 15.46 for depths below $50 \mathrm{~m}$ (standard deviation $=1.30, n=27$, Stas 19-21 and B7).

The saltiest waters that we found, in the bottom of the Jordan Basin, had a salinity of $34.77 \mathrm{~g} \mathrm{~kg}^{-1}$, a temperature of $9.43^{\circ} \mathrm{C}$, and a TIN content of $18.7 \mu \mathrm{gat} \mathrm{N}{ }^{-1}$. These waters differ in composition from the North Allantic slope waters that enter the north-east channel (Pastuszak et al., 1982; Ramp et al., 1985), which have salinities as great as $35.5 \mathrm{~g}$ $\mathrm{kg}^{-1}$ and nitrate concentrations of about $16 \mu \mathrm{gat} \mathrm{N}^{-1}$. Thus, the waters we found in the deeper portions of the Jordan Basin had aged through mixing with overlying waters of lower salinity and nutrient concentration and through nutrient addition via remineralization. We denote these waters as aged slope waters. Wilkinson Basin deep waters have much lower salinities (the highest observed was $34.02 \mathrm{~g} \mathrm{~kg}^{-1}$ with a temperature of $6.9^{\circ} \mathrm{C}$ ) than our aged slope waters and reflect additional isolation from new slope waters entering the north-east channel. Thus, the deep waters within the Wilkinson Basin are aged even more than those in the Jordan Basin.

In contrast to the complex nutrient-salinity relationships (Fig. 2, bottom), the relationships between total inorganic nitrogen, phosphate and silicate appear much simpler. The relationship of TIN nitrogen to phosphate is shown for all data on transects 2 and 9 (Fig. 4, top). For a given concentration of phosphate, nitrogen concentrations are $2-4 \mu$ gat $\mathrm{N}^{-1}$ greater in the eastern Gulf (transect 9) than in the western Gulf (transect 2).

This reduction in the average TIN/PO 4 ratio between the eastern and western Gulf could arise either through the differential removal of nitrogen or addition of phosphate between the two regions within the Gulf, or both. A comparison of phosphate to silicate shows that these two nutrients are transported and remineralized in close association (Fig. 4 , bottom). Concentrations of silicate and phosphate are both low but measurable in surface waters. Below the surface, silicate and phosphate both increase with depth, with Si concentrations as high as $16 \mu$ gat $\mathrm{Si}^{-1}$ in the Jordan Basin and $>27 \mu$ gat $\mathrm{Si}^{-1}$ in the 

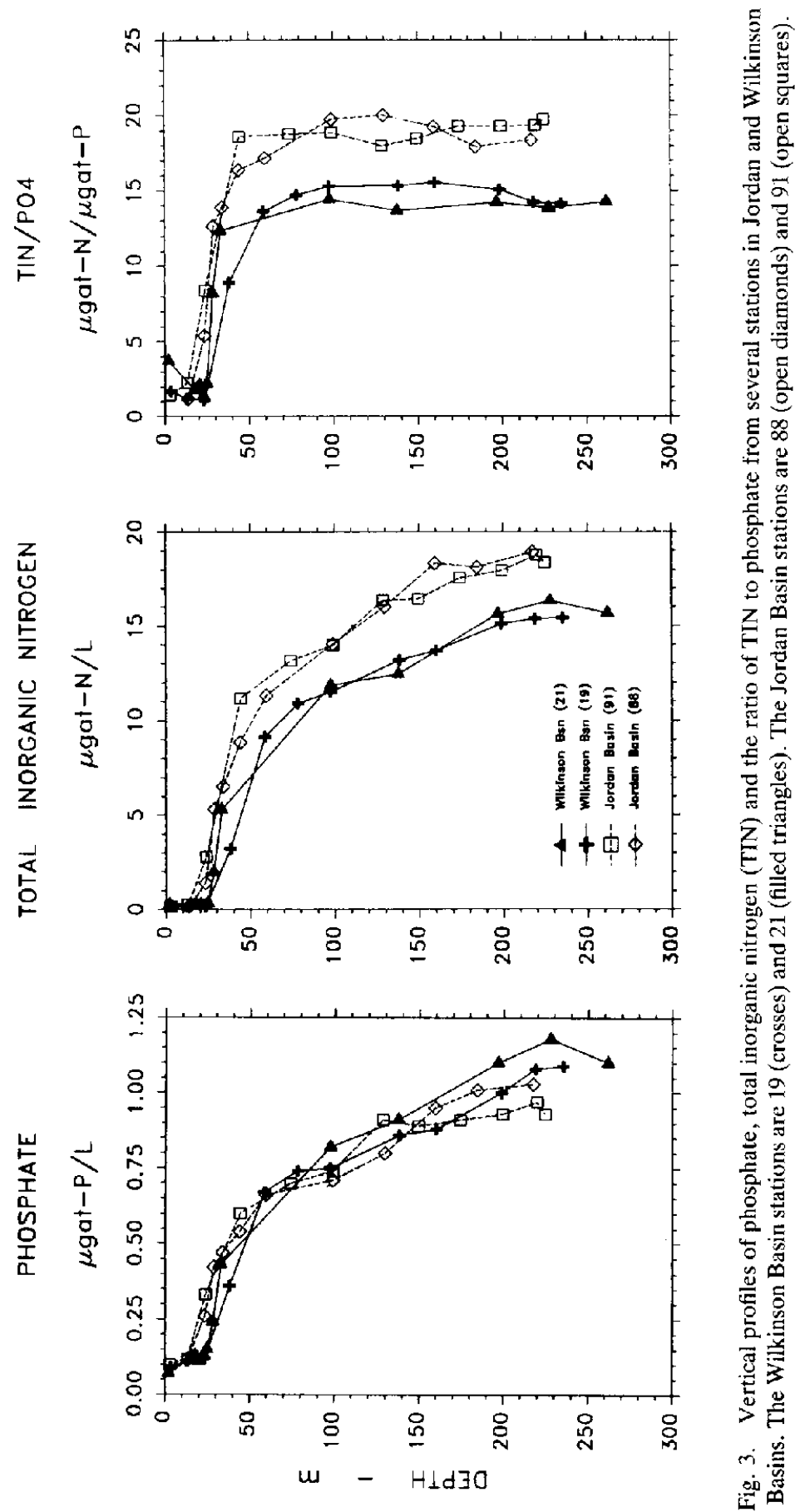

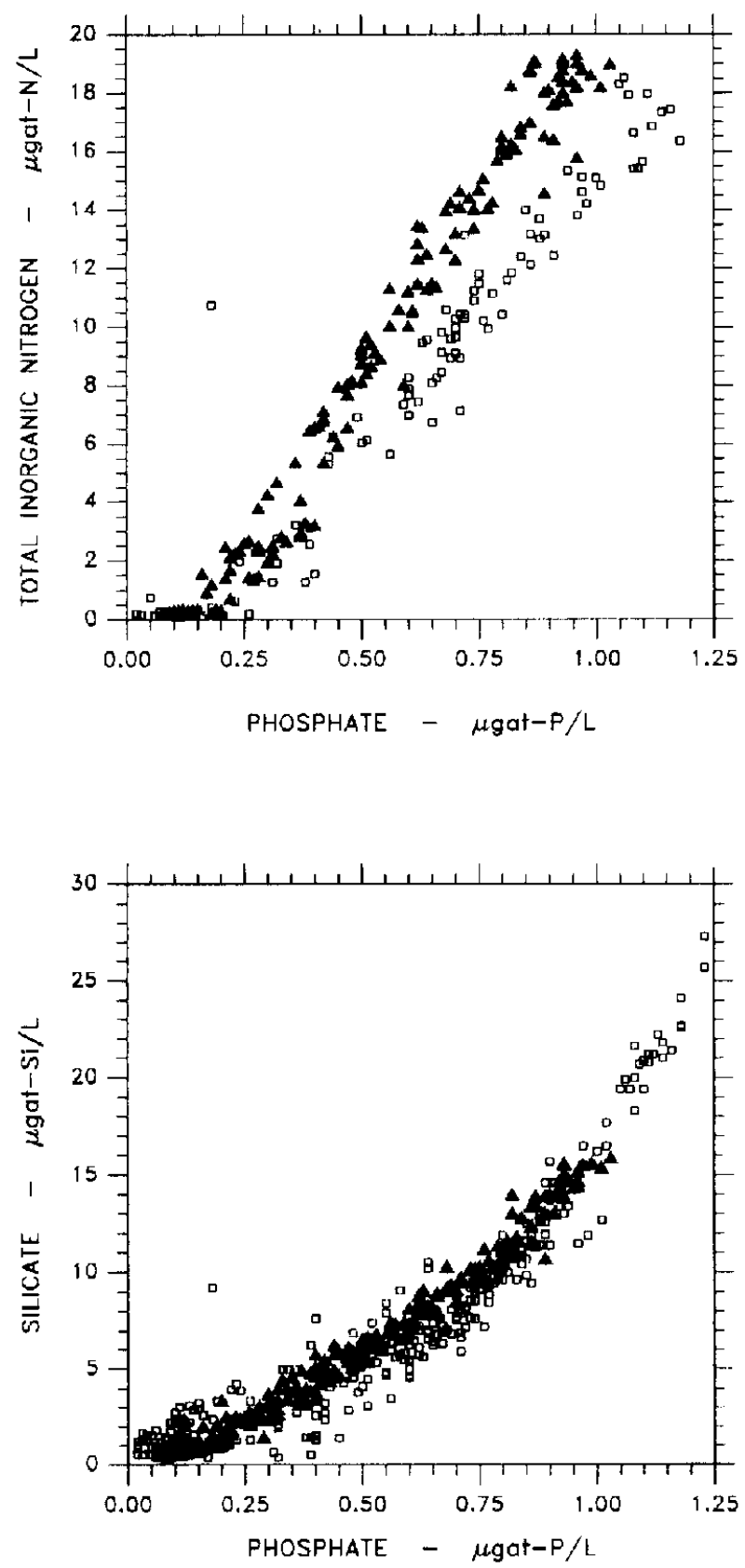

Fig. 4. Relationship between TIN and phosphate (top) and between dissolved silicate and phosphate (bottom) for all samples on transects 2 (open squares) and 9 (filled triangles). 
Wilkinson Basin. The curvilinear relationship between these two nutrients may be accounted for by the more rapid remineralization of phosphate than silicate. This would result in more phosphate release relative to silicate in the upper water column than in bottom waters. What is significant is that the relationship between phosphate and silicate is identical for both the eastern and western Gulf (Fig. 4, bottom). This is important in that it indicates that primary production, vertical sedimentation, and remineralization at depth all operate on the phosphate and silicate distribution to a similar degree between the two regions of the Gulf of Maine. We therefore conclude that the difference between the N-P relationships of the two sides of the Gulf of Maine results from removal of nitrogen relative to $\mathrm{P}$ and $\mathrm{Si}$. Much historical data show that waters within the Gulf remain well oxygenated throughout the year. Thus, sedimentary denitrification would be the most likely removal process.

In this context, one smaller region, Massachusetts and Cape Cod Bays (Fig. 1), appeared to have anomalous nutrient characteristics. These Bays form a somewhat isolated region in that their eastern border adjoining the open Gulf of Maine is partially blocked by Stellwagen Bank, which rises in places to within $30 \mathrm{~m}$ of the sea surface. Stations to the west of Sta. 6 (located on Stellwagen Bank) sampled these Bays. We compared the nutrient--nutrient relations of Stas 7-10 with both the remaining stations of transect 1 located in the open Gulf and with those on transect 2 (Fig. 5). The relationships between TIN and phosphate, TIN and silicate, and silicate and phosphate are identical between stations on transect 1 in the open Gulf and those on transect 2. At comparable depths below $30 \mathrm{~m}$, waters within Massachusetts and Cape Cod Bays had similar phosphate concentrations relative to waters outside in the open Gulf (not shown). However, the waters within Massachusetts and Cape Cod Bays had less TIN vs phosphate, less TIN vs silicate, and slightly more silicate vs phosphate than the waters in the open Gulf (Fig. 5). The slightly elevated relationship of silicate to phosphate suggests either that phytoplankton communities within Massachusetts and Cape Cod Bays may be less dependent on silicate for growth relative to the offshore waters, or that additional sources of silicate occur here. More importantly, the lowering of the ratios of TIN to silicate and of TIN to phosphate relative to outside waters are consistent with the removal of nitrogen via denitrification, in shallow inshore areas.

To investigate more closely the apparent non-stoichiometric loss of nitrogen, we calculated the concentration of missing nitrogen, the $\Delta \mathrm{N}$, based on the measured concentrations of TIN and $\mathrm{PO}_{4}$ (in $\mu$ gat of $\mathrm{N}_{\text {or }} \mathrm{Pl}^{-1}$ ) in individual water samples where,

$$
\Delta \mathrm{N}=\alpha\left[\mathrm{PO}_{4}\right]-[\mathrm{TIN}] .
$$

Here, $\alpha$ is the stoichiometric ratio of inorganic nitrogen to inorganic phosphate. The product, $\alpha\left[\mathrm{PO}_{4}\right]$, is the nitrogen concentration expected in the water sample and $\Delta \mathrm{N}$ is the concentration of missing nitrogen. The stoichiometric ratio, $\alpha$, was set to 19 , that found in the aged slope water in the Jordan Basin. This results in $\Delta \mathrm{N}=0$ for average Jordan Basin waters.

We evaluated the geographic distribution of density, phosphate and $\Delta \mathrm{N}$, bascd on optimal interpolation of the concentrations at $80 \mathrm{~m}$, a depth near the center of the Maine Intermediate Waters. Less dense waters were found in the shallower sites around the periphery of the basin [Fig. 6(A)]. Domes of denser water were found centered over the Wilkinson and Jordan Basins. In the Wilkinson Basin, waters at $80 \mathrm{~m}$ had $\sigma \mathrm{t}$ values less 

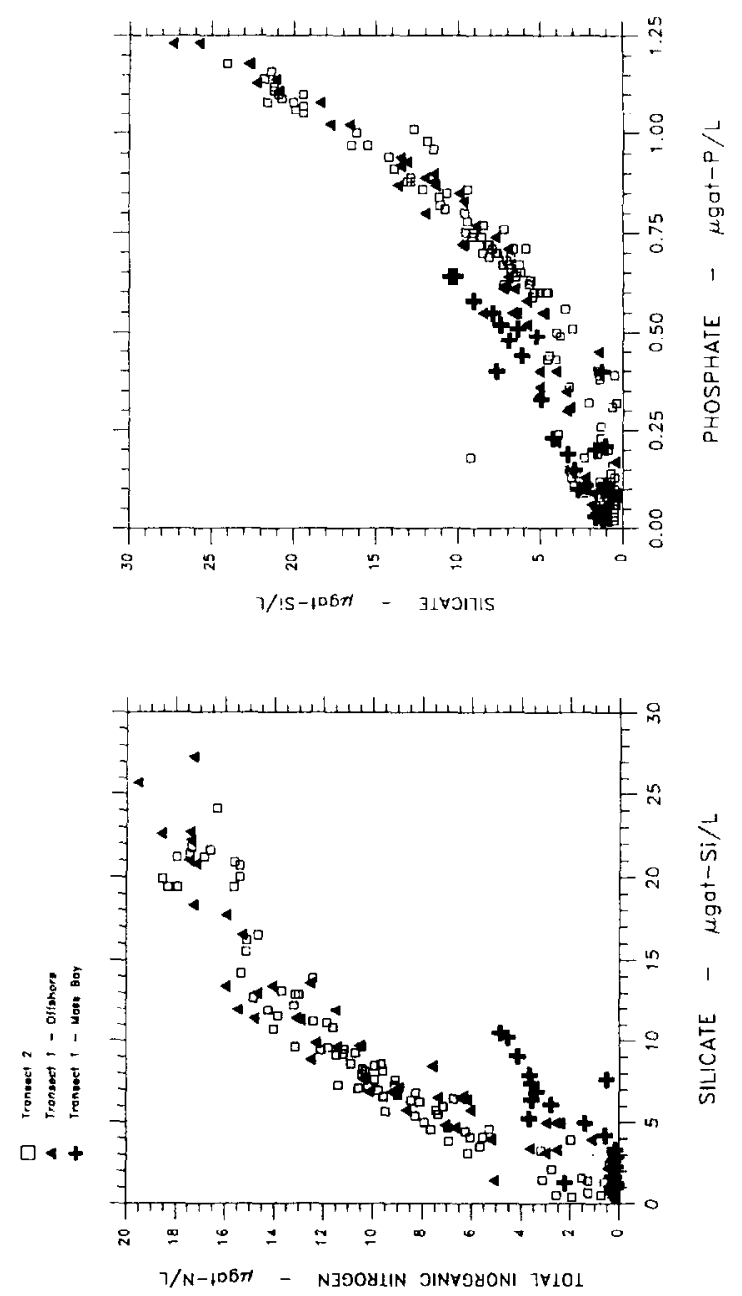

ฐ

$\stackrel{4}{2}$

芯

i.

욜

莒

5

焉

ह

\%

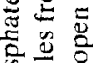

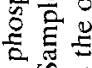

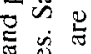

证

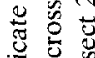

क्षे

$\stackrel{2}{\circ}$

究

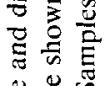

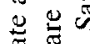

氙 $\frac{1}{0}$

च

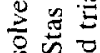

语证

藏焉

¿ 8

ن.

言焉

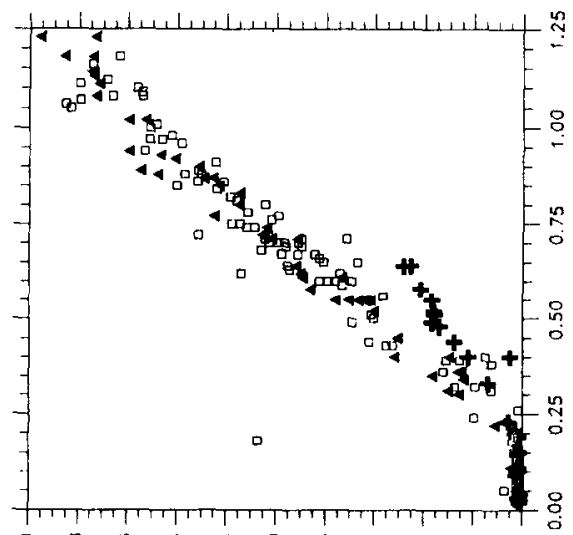

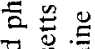

콜

z矛。

要

影

을

ถี

兽焉

동

ن

in

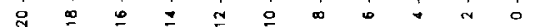

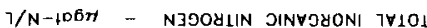




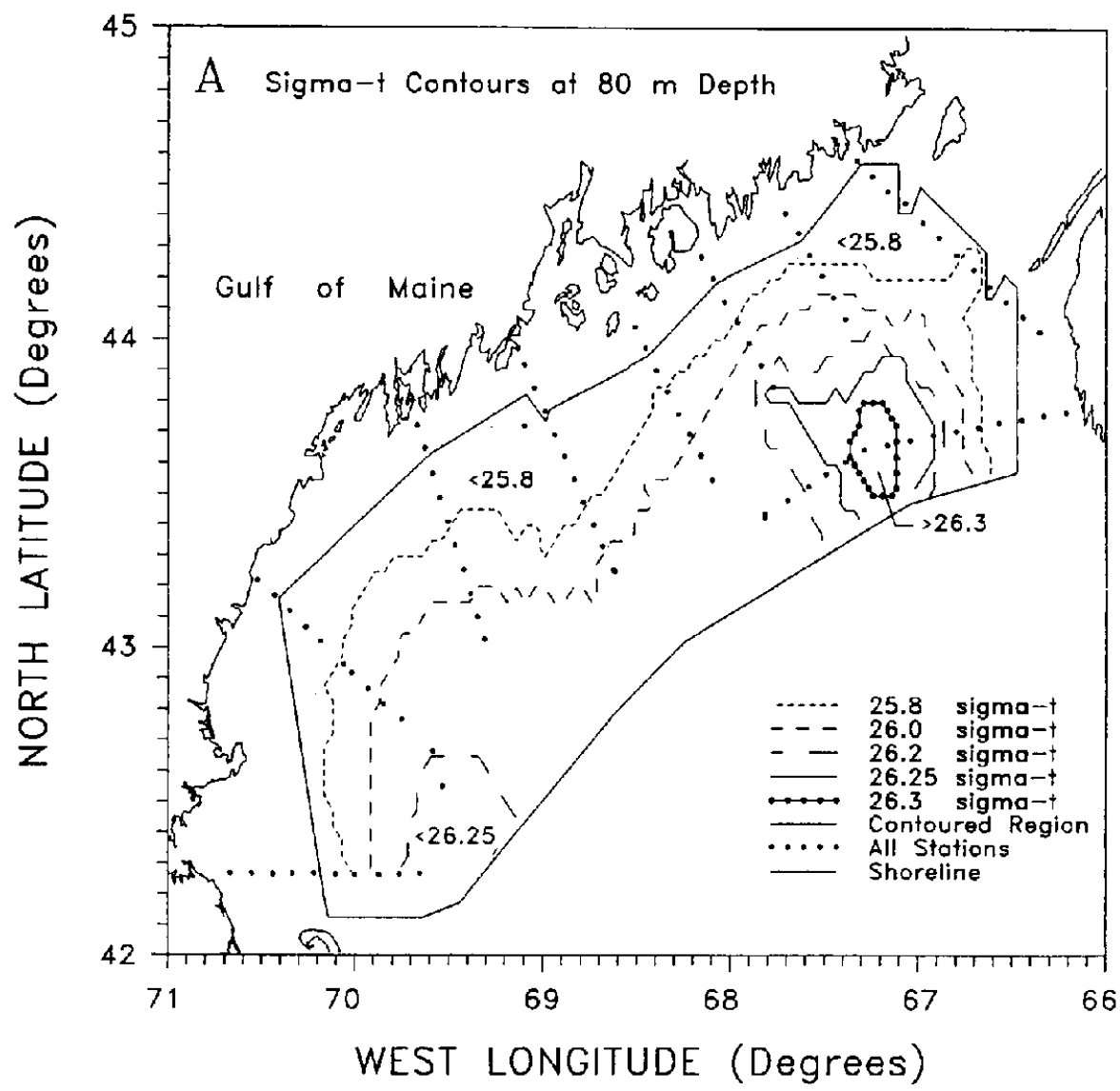

Fig. 6. Distributions of ot (A): phosphate (B); $\Delta \mathrm{N}(\mathrm{C})$; and the standard deviation of $\Delta \mathrm{N}$ (D) at $80 \mathrm{~m}$ in the Gulf of Mainc. Stations are shown as small filled circles. The mapped region, containing all stations sampled from the sea surface to below $80 \mathrm{~m}$, is outlined. Distributions werc obtained by optimal interpolation. Contour intervals are shown on the legends.

than $26.25 \mathrm{mg} \mathrm{l}^{-1}$, while in the Jordan Basin waters of $\sigma$ values greater than $26.3 \mathrm{mg} \mathrm{I}^{-1}$ were found.

Phosphate contours at $80 \mathrm{~m}$ only partially reflected the density field [Fig. 6(B)]. Lowest phosphate concentrations (less than $0.60 \mu$ gat $\mathrm{P} \mathrm{I}^{-1}$ ) were found in the shallower sites off of Nova Scotia and just south of the Bay of Fundy. Whereas $\sigma$ contours easily depicted the denser waters within Jordan Basin, no similar feature appeared in the phosphate distribution. Highest contour levels were found in a north-south oriented tongue located west of Jordan Basin. This feature, centered at about $68.3^{\circ} \mathrm{W}$ longitude, extended over the central plateau region separating the two basins (Fig. 1). Moderately high phosphate concentrations also appeared in a northward extending tongue centered over Wilkinson Basin. Moderate concentrations $\left(0.65-0.70 \mu\right.$ gat $\left.\mathrm{P}^{-1}\right)$ were found over the remainder of transects 1-4 in the western Gulf. Importantly, the two tongues of moderately high phosphate extended over both shallow and deep sites. This suggests that phosphate remineralization may occur both inshore and in the offshore waters. 


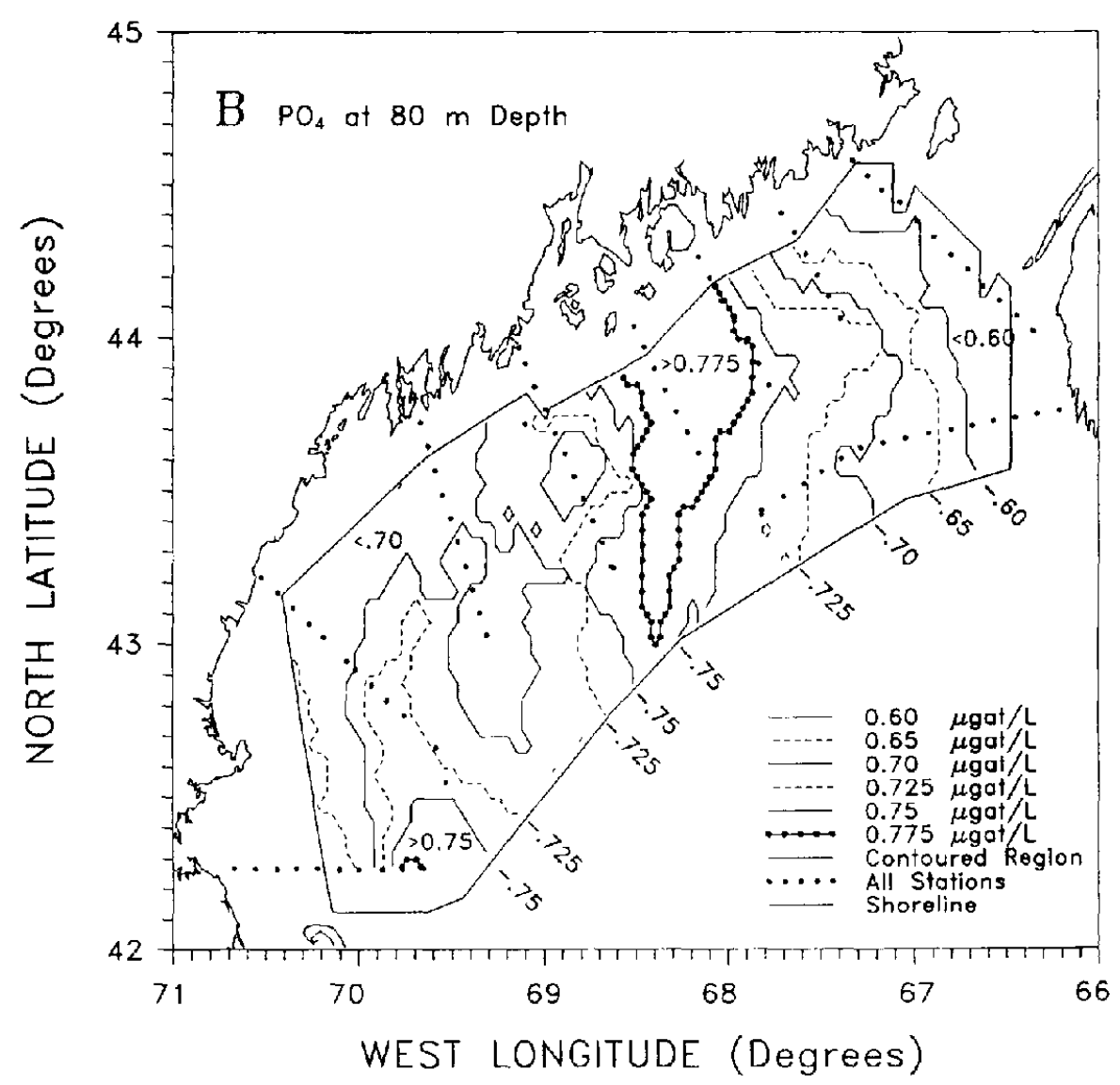

Fig. 6. (Continued.)

Contours of $\Delta \mathrm{N}$ at $80 \mathrm{~m}$ differed from both ot and phosphate [Fig. 6(C)]. Lowest contours $\left(<0.50 \mu\right.$ gat $\left.\mathrm{N}^{1}{ }^{1}\right)$ were solely found in central Jordan Basin, reflecting the high average TIN $/ \mathrm{PO}_{4}$ ratios of the aged slope waters. Highest $\Delta \mathrm{N}$ concentrations $(>4.0 \mu$ gat $\mathrm{N}$ $\left.\mathrm{I}^{-1}\right)$ were found in a rounded tongue in the shallower northern sites on the central plateau. Moderately high concentrations $\left(>3.0 \mu \mathrm{gat} \mathrm{N}^{-1}\right.$ ) were also found in shallow sites on the western side of the contoured region. Relatively low $\Delta \mathrm{N}$ concentrations $(0.5-2.0 \mu$ gat $\mathrm{N}$ $\left.1^{-1}\right)$ were found in and northward of Wilkinson Basin. This pattern is partly similar to $\sigma \mathrm{t}$ in that the basins are somewhat defined by lower values of $\Delta N$, although within the Wilkinson Basin, the region of low $\Delta \mathrm{N}$ is not coincident with the region of high $\sigma \mathrm{t}$. Also, the pattern of $\Delta \mathrm{N}$ does not conform to that of phosphate, whereas the region of highest $\Delta \mathrm{N}$ in the northern tonguc at $69.3^{\circ} \mathrm{W}$ longitude is coincident with the tongue of high phosphate, the phosphate tongue extends well offshore.

By employing optimal interpolation techniques, the distribution of the standard deviation of the mapped estimate were also obtained [Fig. 6(D)]. For $\Delta \mathrm{N}$ at $80 \mathrm{~m}$, low values of the standard deviation (s.d., $<0.75 \mu$ gat $\mathrm{N}^{-1}$ ) were calculated in proximity to the transect lines, and higher values of the s.d. were found well away from the sampling 


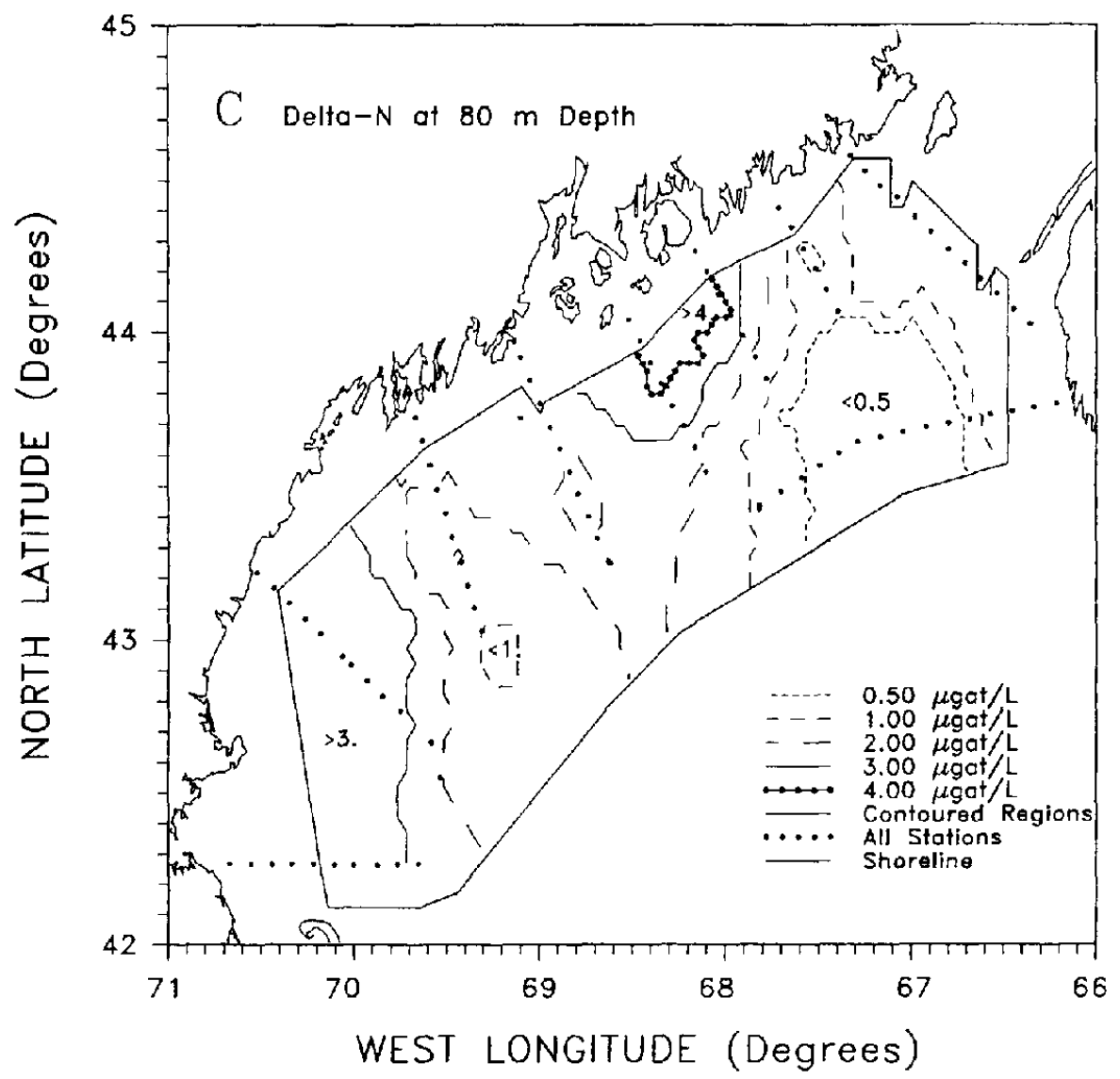

Fig. 6. (Continued.)

sites. Nevertheless, over most of the grid, the standard deviations of $\Delta \mathrm{N}$ were less than $1.25 \mu$ gat $\mathrm{N}^{-1}$. The low values of standard deviation relative to the range in $\Delta \mathrm{N}$ (from about 0 to greater than $4.0 \mu$ gat $\mathrm{N}^{-1}$ ) indicates that the differences in $\Delta \mathrm{N}$ across the Gulf are statistically meaningful.

A similar analysis of the distributions of $\sigma \mathrm{t}$, phosphate, and $\Delta \mathrm{N}$ was done for the depth of $150 \mathrm{~m}$ (Fig. 7). Again, domes of higher density water were found in both Jordan and Wilkinson Basins, the densest being those within the Jordan Basin [Fig. 7(A)]. The phosphate distribution at $150 \mathrm{~m}$ depth [Fig. 7(B)] showed the lowest concentrations occurring on the eastern side of the grid $\left(<0.77 \mu\right.$ gat $\left.\mathrm{Pl}^{-1}\right)$. Moderately low concentrations were also seen in the shallower areas offshore of New Hampshire. The highest concentrations $\left(>1.05 \mu\right.$ gat $\left.\mathrm{P}^{-1}\right)$ were found in the central platcau region between the two deep basins. This region had high phosphate concentrations at $80 \mathrm{~m}$ as well [Fig. $6(\mathrm{~B})] . \Delta \mathrm{N}$ distributions at $150 \mathrm{~m}$ showed lowest concentrations in most of the waters over the Jordan Basin [Fig. 7(C)]. Moderately low concentrations were found in waters of transect 3 . Highest $\Delta \mathrm{N}$ concentrations were found in the central plateau region between the two basins [Fig. $7(\mathrm{C})]$, coincident with the tongue of high phosphate concentrations at the 


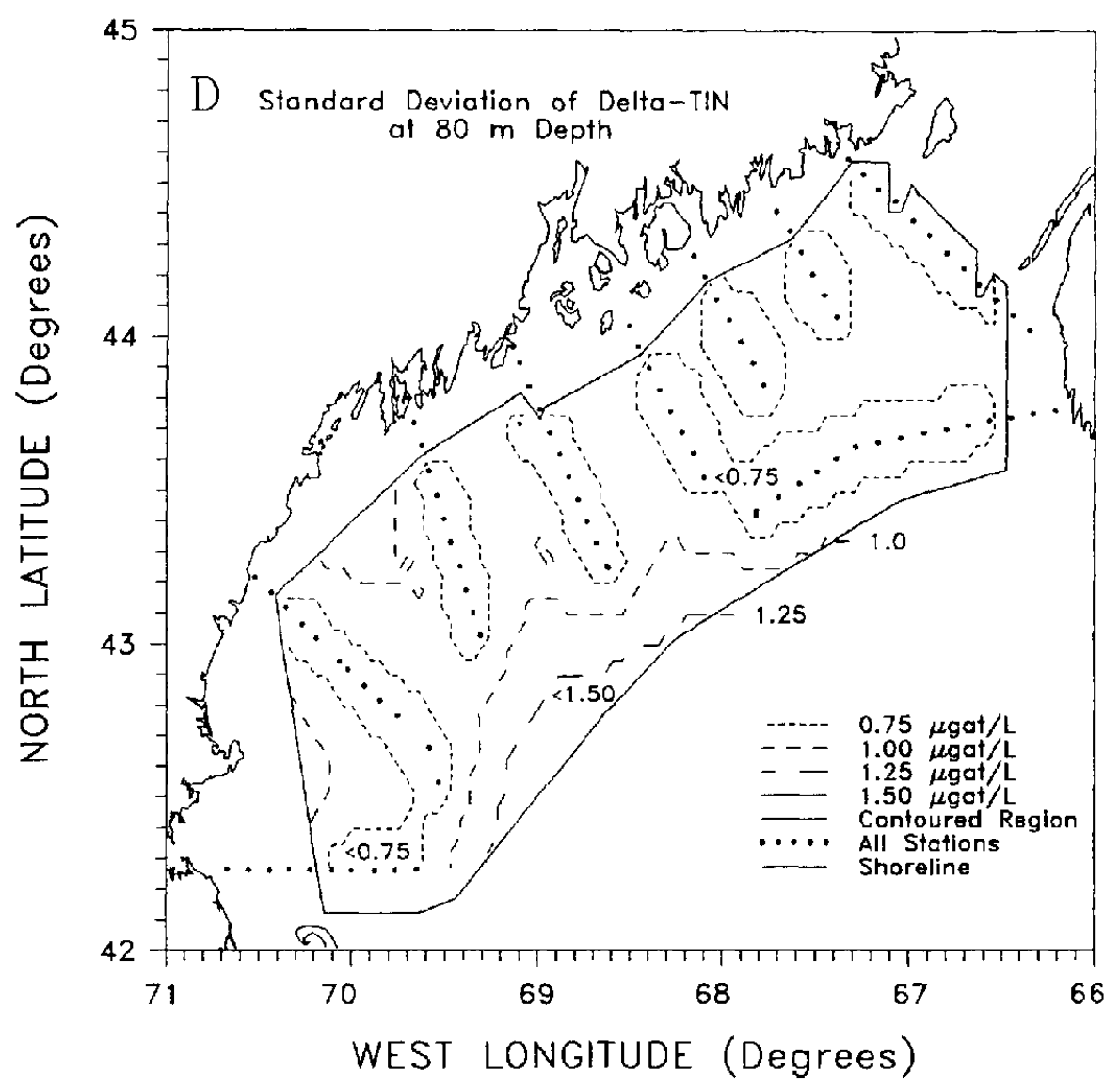

Fig. 6. (Continued.)

same depth [Fig. 7(B)]. These high $\Delta \mathrm{N}$ concentrations occurred where the contour level was close to the sediments (generally within $25 \mathrm{~m}$ ). Based on contours from both $80 \mathrm{~m}$ and $150 \mathrm{~m}$, we concluded that the central plateau region with high phosphate concentrations at both depths represents an area of intense nutrient regeneration [Figs 6(B) and 7(B)]. Within this region, highest $\Delta \mathrm{N}$ concentrations coincide with clevated phosphate only at depths close to the sediments. $\Delta \mathrm{N}$ was not greatly elevated at $80 \mathrm{~m}$ in the offshore waters containing high phosphate [Fig. 6(C)], waters which apparently lacked direct contact with the sediments. Thus, we suspect that rapid sedimentary denitrification in the biologically rich sediments on this plateau caused the high $\Delta N$ values observed at $150 \mathrm{~m}$ but not at $80 \mathrm{~m}$.

\section{DISCUSSION}

We expected the nutrient cycle in the Gulf of Maine to be dominated by the seasonal cycle of primary production. In winter, convection and mixing of waters in the upper $130 \mathrm{~m}$ results in high concentrations of nutrients in the surface layers. Springtime water column stratification promotes phytoplankton blooms which soon deplete the surface layers of 


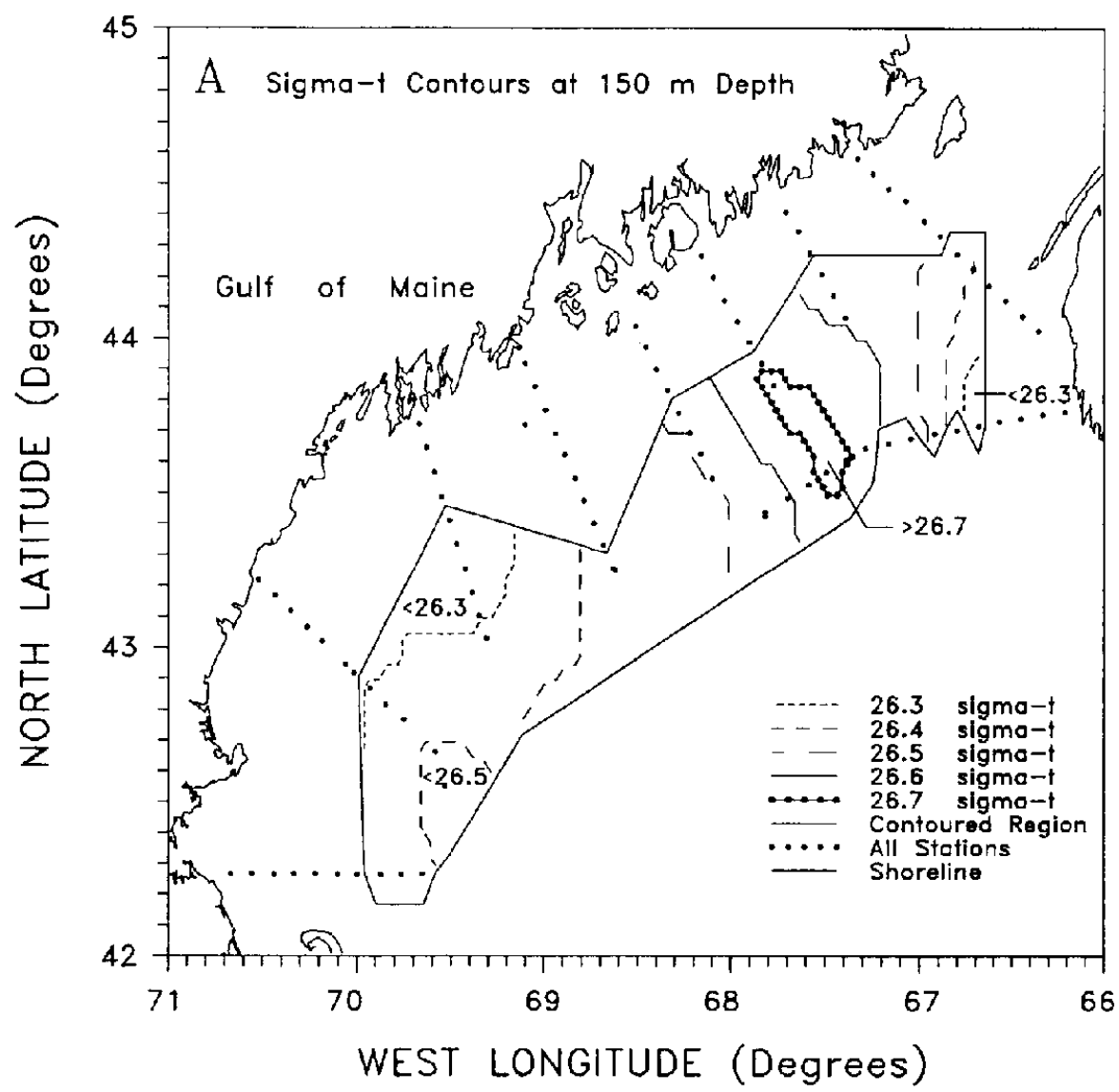

Fig. 7. Distributions of $\sigma(\Lambda)$; phosphate (B); and $\Delta N(C)$ at $150 \mathrm{~m}$ in the Gulf of Maine. Stations are shown as small filled circles. The outlincd region is that mapped by optimal interpolation.

Contour intervals are shown on the legends.

nutrients (Townsend, 1991). Organic material sinks from the surface layers to depth and, in part, is remineralized in the water column and, in part, is deposited on the sediments. Without consideration of lateral circulation, this seasonal cycle would act to strip nutrients from the upper water layers and accumulate them at depth over the spring and summer period until such time in the cycle that a steady-state vertical nutrient distribution was approached.

Within this cycle, sedimentary denitrification would remove inorganic nitrogen in two ways (Christensen et al., 1987). In sediments where nitrate concentrations continually decrease from the sediment-water interface to the depth of nitrate exhaustion within the sediments, denitrification would directly lower bottom water nitrate concentrations. Alternately, organic matter decay within the sediments releases ammonium which may be oxidized to nitrate, nitrite, or nitrous oxide via bacterial nitrification. These intermediate compounds may then be consumed by denitrification. This latter mechanism appcars to be most important in the basin sediments (Christensen et al., 1992). Here, the rate of denitrification is influenced by the rates of deposition and accumulation of organic matter, 


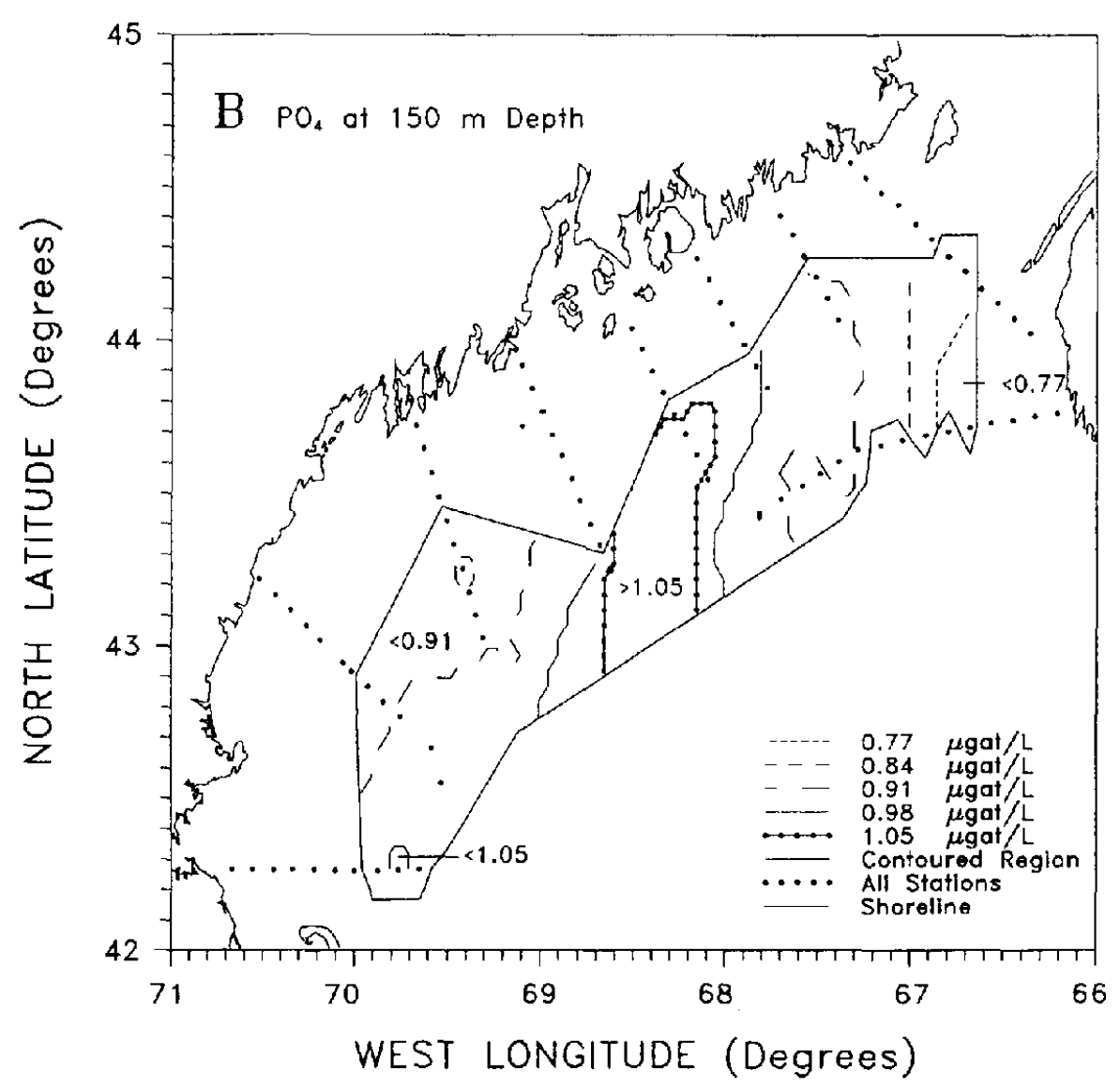

Fig. 7. (Continued.)

the rate of decay of this material and the rate of nitrification. Since organic matter degradation in sediments may occur over much longer time-scales than occur in the cycle of phytoplankton bloom and organic matter sinking and deposition on the sediment surface, we expect denitrification rates to be less influenced by seasonality than is water column nutrient regeneration. Furthermore, rates of denitrification are much lower in the deep basins than in shallow sites.

Our water column results from the mid-summer reflect this view of nutrient regeneration and denitrification. Most important was the observation that the nutrient relationships in the intermediate and bottom waters differed between the eastern and western Gulf of Maine. In the eastern Gulf, bottom waters were most influenced by the introduction of nutrient-rich North Atlantic slope water. Although the waters in the bottom of Jordan Basin have aged relative to newly cntered slope water, these waters are probably the youngest of those we observed at intermediate and bottom depths in the Gulf. During this aging process, remineralization increases their nutrient content, and when added to the already high nitrate concentrations in the newly injected slope waters, TIN concentrations in the bottom waters of Jordan Basin were the highest within the Gulf. Phosphate and 


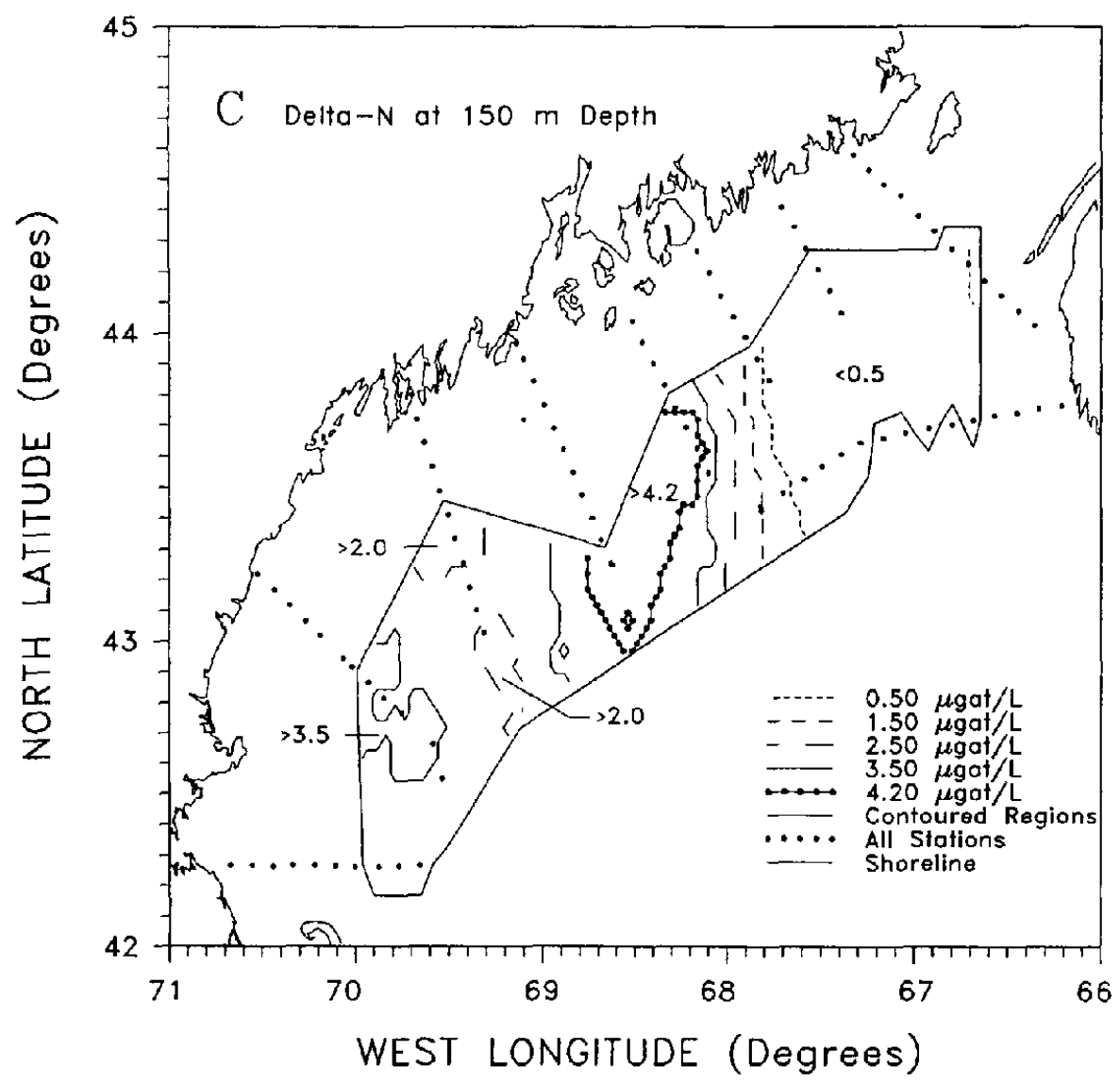

Fig. 7. (Continued.)

silicate were also moderately rich in these waters. Denitrification may have impacted these aged slope waters, but because the waters appear to be relatively young, and because they reside at depths where denitrification rates are much lower, remineralization appears to have dominated over denitrification. In contrast, bottom waters in Wilkinson Basin contained the highest concentrations of phosphate and silicate, while TIN concentrations had been lowered. This basin tends not to receive much slope water as it transits the northeast channel. In our data, the Wilkinson Basin bottom waters were colder and much less salty than those in the Jordan Basin which suggests that they resided in the Wilkinson Basin much longer, perhaps even through the previous winter. Both the affect of the seasonal cycle of sinking organic matter flux and remineralization and the affect of more steady rates of denitrification over a longer time, in combination, appeared to have increased the phosphate and silicate concentrations at the expense of inorganic nitrogen in the bottom waters of Wilkinson Basin.

Although we showed that the nutrient distributions differed between the castern and western sides of the Gulf, geostatistical mapping of the nutrient distributions at intermediate depths demonstrated unexpectedly high nutrient waters above the central plateau 
separating Jordan and Wilkinson Basins. Maps of ot at both $80 \mathrm{~m}$ and $150 \mathrm{~m}$ depth clearly indicated the domes of denser water within the deep basins, and the distributions of phosphate showed lowest concentrations in the eastern Gulf. However, the rcgions of highest phosphate were found on the central plateau, both inshore and offshore, suggesting that significant water column remincralization may occur in this mid-Gulf region. From the measured phosphate and TIN concentrations, we derived the property, $\Delta \mathrm{N}$, which estimates the concentration of nitrogen lost from the water column. As expected, based on the location of aged slope waters, the distribution of $\Delta \mathrm{N}$ at both 80 and $150 \mathrm{~m}$ depth showed lowest concentrations in the eastern side of the Gulf (the Jordan Basin). Highest concentrations of $\Delta \mathrm{N}$ coincided with the locations of the highest phosphate in the central plateau region. Although this region showed enriched phosphate concentrations throughout much of the water column, high $\Delta \mathrm{N}$ concentrations were only found near the sediments, suggesting that sediment denitrification caused the loss of nitrogen.

The degree of nitrogen loss (i.c. the magnitude of $\Delta N$ ) was dependent on the stoichiometry of nitrogen to phosphate. We used a value of 19 , consistent with the obscrved ratio for bottom waters in the Jordan Basin. This factor is greater than the traditional Redfield N/P ratio of 16 (Takahashi et al., 1985), but we suggest that the N/P ratio of 19 is that which would occur if denitrification were not significant within the Gulf. In our concept, this higher ratio results from the operation of two factors. Assuming that phosphate is preferentially recycled faster than inorganic nitrogen, as suggested by Minster and Boulahdid (1987), organic matter sinking out of the surface layers would have a slightly greater N/P content than when this material was initially formed. Coupled to this enrichment is the circulation of the Gull, where nutricnt-rich waters enter at depth and nutrient-depleted surface waters arc flushed out. Since inorganic nitrogen is more completely stripped from the upper waters than is phosphate, the exiting surface waters would contain proportionally more phosphate than nitrogen. Thus, these two processes would act to reflux nitrogen at the expense of phosphate and would result in the ratio of the rcmaining TIN to phosphate being greater than the classical Redfield ratio, as we found in the Jordan Basin. Within this systematic view, denitrification counteracts this nitrogen accumulation by lowering the TIN to phosphate ratio to approximatcly 15 in most of the intermediate and deep waters outside of Jordan Basin. Greater reduction in this ratio would occur if waters were to become more isolated from deep water renewal, as was seen in our data from Massachusetts and Cape Cod Bays.

\subsection{Denitrification rates based on $\Delta \mathrm{N}$ and residence times}

The overall rate of denitrification can be assessed based on the average $\Delta N$ of the waters within the Gulf and the residence time. Based on a average $\Delta N$ of $2 \mu$ gat $N^{-1}{ }^{-1}$ in all waters of the Gulf (total volume of $15.587 \times 10^{12} \mathrm{~m}^{3}$, Brown and Beardsley, 1978) and assuming that this depletion occurred over the average residence time of the waters of the Gulf (one year), the denitrification rate would have been $31.2 \times 10^{9}$ gat $\mathrm{N}^{-1}$. This rate could have been larger if nitrogen depletion occurred in a shorter time period. Based on our data, no large $\Delta \mathrm{N}$ values were observed in waters within the surface mixed layer and within the Jordan Basin. These waters represented about half of the total volume. Applying the $\Delta N$ value of $3 \mu \mathrm{gat} \mathrm{N}{ }^{-1}$ to the remaining $50 \%$ of the waters within the Gulf, the total depletion would have been $23.4 \times 10^{9}$ gat N. Assuming that this depletion occurred between the six 
months from the end of the winter convection season and our cruise in mid-July, the rate of

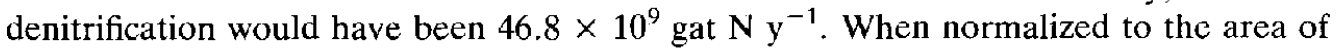
sediments $\left(123.0 \times 10^{9} \mathrm{~m}^{2}\right.$; Brown and Beardslcy, 1978), the average sedimentary denitrification rate would be $0.80-1.21$ pgat $\mathrm{N} \mathrm{cm}^{-2} \mathrm{~s}^{-1}$.

\subsection{Salinity, phosphate and nitrogen budgets of the Gulf of Maine}

Schlitz and Cohen (1984) constructed the first inorganic nitrogen budget based on current meter and nutrient concentration measurements in the inflowing and exiting waters. Based on a measured inflow of $276,000 \mathrm{~m}^{3} \mathrm{~s}^{-1}$ (Ramp et al., 1985), Schlitz and Cohen (1984) estimated that $61 \%$ of the waters entering the Gulf travels through the north-east channel. With an annually averaged combined $\mathrm{NO}_{3}^{-}+\mathrm{NH}_{4}^{+}$concentration of $21 \mu$ gat N I${ }^{-1}$ (based partly on data of Pastuszak et al., 1982), these waters account for 83\% of the nutrient input into the Gulf. Waters from the Scotian Continental Shelf accounted for $31 \%$ of the total water inflow $\left(170,000 \mathrm{~m}^{3} \mathrm{~s}^{-1}\right)$, but these waters have lower $\mathrm{NO}_{3}^{-}$and $\mathrm{NH}_{4}^{1}$ concentrations ( $6.5 \mu$ gat $\mathrm{N}^{-1}$ total as an annual average). Thus, Scotian Shelf waters account for only $16 \%$ of the nitrogen inputs. River inflow and the excess of precipitation over evaporation accounted for $2 \%$ of the water inflows $\left(7900 \mathrm{~m}^{3} \mathrm{~s}^{-1}\right)$ and $3 \%$ of the nitrogen inputs. The sum of all inputs of inorganic nitrogen was $222.3 \times 10^{9}$ gat $\mathrm{N}^{-1}$. Schlitz and Cohen (1984) identified the outflowing waters as those flowing along the New England Shelf. Volume flows were $390,000 \mathrm{~m}^{3} \mathrm{~s}^{-1}, 86 \%$ of the estimated inflow into the Gulf. With a combined concentration of nitrate and ammonium being $4.45 \mu \mathrm{gat} \mathrm{N}^{-1}$, this flow would remove $54.9 \times 10^{9}$ gat $\mathrm{N} \mathrm{y}{ }^{1}$ from the Gulf of Maine. As the nitrogen inflow greatly exceeds the outflow, this results in a net input of inorganic nitrogen of 167.4 $\times 10^{9}$ gat $\mathrm{N}^{-1}$, which must be balanced by additional biologically mediated losses. Schlitz and Cohen (1984) did not identify these additional losses.

Although our discovery of nitrogen depletion in the waters within the Gulf led us to believe that significant denitrification is the cause for the nitrogen imbalance discussed by Schlitz and Cohen (1984), we re-evaluated their nutrient budget and developed corresponding and consistent salt and phosphate budgets (Table 1).

We suspected that the nitrogen inputs via the north-east channel may have been overestimated. Schlitz and Cohen (1984) used a nitrate concentration of $14.4 \mu \mathrm{gat} \mathrm{N} \mathrm{^{-1 }}$ and an ammonium concentration of $6.5 \mu \mathrm{gat} \mathrm{N}{ }^{1}{ }^{1}$ in these waters. We examined several data sets, including some of the NODC data used by Schlitz and Cohen (1984). Although about half of the nutrient data sets appeared to be of uncertain quality, especially with regard to phosphate and silicate concentrations, several profiles of salinity, nitrate + nitrite, phosphate, and the N/P ratio from apparently good data sets are presented (Fig. 8). These data show that both salinity and nutrients in the north-cast channel have strong vertical gradients which were not reflected in the budget of Schlitz and Cohen (1984). Although the high-salinity, nitrate-rich slope waters which enter the Gulf act to drive the nutrient cycle of the Gulf, these waters are typically found at depth in the north-east channel, and they represent only a fraction of the entering waters. To better estimate the annual average salinity and nutrient content of in the north-east channel, we used monthly averages of salinity and nitrate concentrations for the intermediate waters $(65-120 \mathrm{~m})$ and bottom waters $(>120 \mathrm{~m})$ as provided by Pastuszak et al. (1982). Based on these averages, salinity varied slightly with season. At intermediate depths, salinity averaged $32.83 \mathrm{~g} \mathrm{~kg}^{-1}$ in winter (October-February) and $33.114 \mathrm{~g} \mathrm{~kg}^{-1}$ in the remainder of the year. Below 
Table 1. Annual salinity, phosphate and nitrogen budgets for the Gulf of Maine. Organic matter export, at the rate of $1.5 \%$ of the primary production of the Gulf of Maine (Schlitz and Cohen, 1984), was used to balance the phosphate budget. Sedimentary denitrification was used to balance the nitrogen budget. The resulting denitrification rate per sediment area was $0.85 \mathrm{pg}$ at $\mathrm{N} \mathrm{cm}^{-2} \mathrm{~s}^{-1}$. The area of $123.0 \times 10^{9} \mathrm{~m}^{2}$ and volume of $15.587 \times 10^{12} \mathrm{~m}^{3}$ were from Brown and Beardsley (1978)

\begin{tabular}{|c|c|c|c|c|c|c|c|}
\hline \multirow[t]{2}{*}{ Process and region } & \multirow{2}{*}{$\begin{array}{l}\text { Volums } \\
\text { flow } \\
10^{3} \mathrm{~m}^{3} \mathrm{~s}^{-1}\end{array}$} & \multirow{2}{*}{\multicolumn{2}{|c|}{$\begin{array}{cc} & \text { Salinity } \\
\text { conc. } & \text { rate } \\
\mathrm{g} \mathrm{kg}^{-1} & 10^{6} \mathrm{~g} \mathrm{~m}^{3} \mathrm{~kg}^{-1} \mathrm{~s}^{-1}\end{array}$}} & \multicolumn{2}{|c|}{ Phosphate } & \multicolumn{2}{|c|}{ Nitrogen } \\
\hline & & & & $\underset{\mu \mathrm{gat} \mathrm{l^{-1 }}}{\left[\mathrm{PO}_{4}\right]}$ & $\begin{array}{l}\text { rate } \\
10^{9} \text { gat }^{-1}\end{array}$ & $\underset{\mu \text { gat I }}{[\mathrm{TIN}]}$ & $\begin{array}{c}\text { rate } \\
10^{9} \text { gat y }\end{array}$ \\
\hline \multicolumn{8}{|l|}{ Advective inputs } \\
\hline north-east channel & 262 & 33.537 & 8.787 & 0.74 & 6.11 & 12.6 & 104.1 \\
\hline Scotian Shelf & 200 & 32.40 & 6.480 & 0.40 & 2.52 & 5.0 & 31.5 \\
\hline rivers and rainfall & 4 & 0.0 & 0.0 & 0.50 & 0.06 & 23.78 & 3.0 \\
\hline Total inputs & 466 & & 15.267 & & 8.69 & & 138.6 \\
\hline \multicolumn{8}{|l|}{ Advective outputs } \\
\hline New England Shelf & -466 & 32.75 & -15.262 & 0.55 & -8.08 & 6.5 & -95.5 \\
\hline Net advective input & & & 0.005 & & 0.61 & & 43.1 \\
\hline \multicolumn{8}{|l|}{ Non-advective losses } \\
\hline burial & & & & & -0.26 & & -4.4 \\
\hline organic matter expo & & & & & -0.35 & & -5.6 \\
\hline denitrification & & & & & 0.0 & & -33.1 \\
\hline Total non-advertive lot & sises & & & & -0.61 & & -43.1 \\
\hline Sum of net advection a & ind burial & & 0.005 & & 0.35 & & 38.7 \\
\hline
\end{tabular}

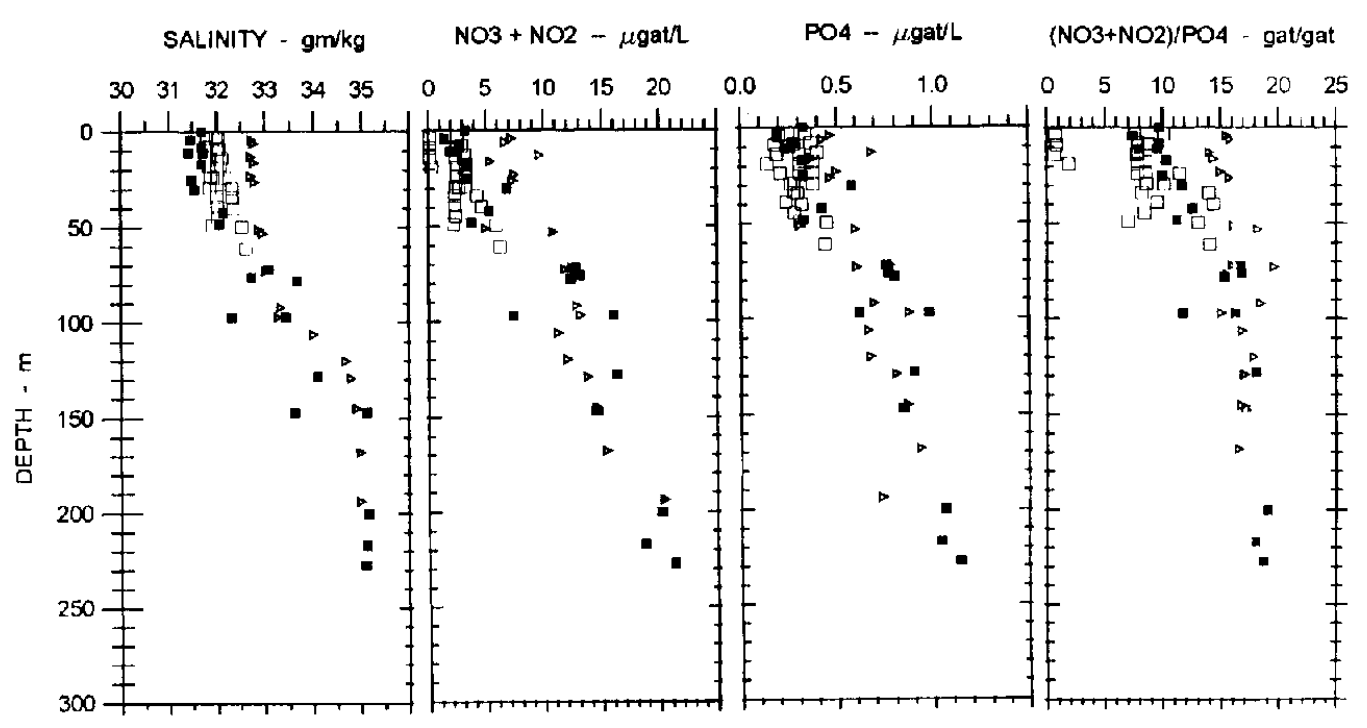

Fig. 8. Vertical profiles of salinity, nitrate + nitrite, phosphate, and the ratio of nitrate + nitrite to phosphate from the north-east channel and the Scotian Shelf. North-east channel data were NODC data from 1975 and 1976. On 5-6 December 1975, four stations at $42.25^{\circ} \mathrm{N} 66.000^{\circ} \mathrm{W}$, $42.486^{\circ} \mathrm{N} 66.033^{\circ} \mathrm{W}, 42.50^{\circ} \mathrm{N} 66.451^{\circ} \mathrm{W}$ and $41.983^{\circ} \mathrm{N} 66.017^{\circ} \mathrm{W}$ were represented by filled squares. On $12-13$ February 1976 , two stations at $42.133^{\circ} \mathrm{N} 66.267^{\circ} \mathrm{W}$ and $42.233^{\circ} \mathrm{N} 66.500^{\circ} \mathrm{W}$ were represented by partially filled triangles. Stations $77-79$ from our transect 9 near Yarmouth, Nova Scotia, are shown as open boxes. 
$120 \mathrm{~m}$, the average salinity was $33.845 \mathrm{~g} \mathrm{~kg}^{-1}$ in winter and $34.196 \mathrm{~g} \mathrm{~kg}^{-1}$ in the rest of the year. Since nitritc was not measured, the reported nitrate concentrations must represent the combined analysis of both nitrate and nitrite. Little seasonal change occurred in the nitrate + nitrite content of the intermediate and deeper waters of the channel and so we used the annual averages of $9.85 \mu$ gat $\mathrm{N}^{-1}$ (intermediate depths) and $14.9 \mu$ gat $\mathrm{N}^{-1}$ (deep waters). Unlike Schlitz and Cohen (1984), wc found little evidence of high ammonium concentrations in the north-east channel. In our own data from the central Gulf, ammonium concentrations generally were less than $0.2 \mu$ gat $\mathrm{N}^{-1}$. We assigned the nitrate + nitrite concentration as the value for TIN of the channel. For phosphate, NODC data as well as more recently unpublished data showed that the ratio of $\left(\mathrm{NO}_{3}^{-}+\right.$ $\mathrm{NO}_{2}^{-}$)/ $\mathrm{PO}_{4}^{-3}$ averaged about $17-18$ in the north-east channel (Fig. 8). Using a ratio of 17 , we estimated the annual averaged phosphate concentration from our nitrate and nitritc averages (Table 1 ).

To estimate total transports, we applied these average salinity and nutrient concentrations to the flows measured by Ramp et al. (1985). As a two-year average for a transect line of current meter moorings spanning the north-east channel, the inflow of all waters below $75 \mathrm{~m}$ was $262,000 \mathrm{~m}^{3} \mathrm{~s}^{-1}$. They sub-divided the inflowing waters into those deep in the channel (below $120 \mathrm{~m}$ ), and those at intermediate depths $(75-120 \mathrm{~m})$, but did not provide the average flow in each depth interval. They did show the cross-sectional areas applied to cach current meter record. For the intermediate depths, the total area was $2,801,000 \mathrm{~m}^{2}$, and below $120 \mathrm{~m}$, the total area was $3,222,000 \mathrm{~m}^{2}$. Temporal averages of the total flow were also shown for four six-month periods covered by the current meter record. Based on these results, we calculated the inflow of salt, nitrogen and phosphate in the north-east channel to be $8.787 \times 10^{9}\left(\mathrm{~g} \mathrm{~kg}^{-1}\right)\left(\mathrm{m}^{3} \mathrm{~s}^{-1}\right)$ for salinity, $6.11 \times 10^{9}$ gat $\mathrm{P} \mathrm{y}^{-1}$ for phosphate, and $104.1 \times 10^{9}$ gat $\mathrm{N} \mathrm{y}^{-1}$ for TIN (Table 1). From these, annually averaged concentrations were calculated $\left(33.537 \mathrm{~g} \mathrm{~kg}^{-1}, 0.74 \mu\right.$ gat $\mathrm{P} \mathrm{I}^{-1}$ and $12.6 \mu$ gat N $\left.{ }^{-1}\right)$. The average TIN concentration is significantly less than that used by Schlitz and Cohen (1984) primarily due to our elimination of their unusually high ammonium concentrations and due to our use of lower nitrate + nitrite concentrations at intermediate depths. Brown and Beardsley (1978) calculated a salinity budget for the Gulf in which the slope water component had a salinity of $35.0 \mathrm{~g} \mathrm{~kg}^{-1}$ and an inflow rate of $120,000 \mathrm{~m}^{3} \mathrm{~s}^{-1}$. Assuming that our average north-east channel inflow represents a mixture solely of Scotian Shelf water (salinity $=32.4 \mathrm{~g} \mathrm{~kg}^{-1}$ ) and slope water $\left(35.0 \mathrm{~g} \mathrm{~kg}^{-1}\right)$, our total inflow would represent a mixture of $147,000 \mathrm{~m}^{3} \mathrm{~s}^{-1}$ of Scotian Shelf water and $115,000 \mathrm{~m}^{3} \mathrm{~s}^{-1}$ of slope water, nearly identical to the slope water inflow of Brown and Beardsley (1978).

The second most important source of water to the Gulf of Maine is from the Scotian Shelf. Schlitz and Cohen (1984) used a total inflow rate of $170,000 \mathrm{~m}^{3} \mathrm{~s}^{-1}$. Drinkwater et al. (1979) calculated the geostrophic volume transports along the Scotian Shelf off Halifax. This Scotian Shelf current had an annual flow of $350,000 \mathrm{~m}^{3} \mathrm{~s}^{-1}$ and $75 \%$ of this occurred over the inshore third of the shelf. Sutcliffe et al. (1976) found that the net alongshore transport through the Halifax section was $280,000 \mathrm{~m}^{3} \mathrm{~s}^{-1}$. Brown and Beardsley (1978) uscd $200,000 \mathrm{~m}^{3} \mathrm{~s}^{-1}$ as a lower limit for the inflow across the Scotian Shelf and into the Gulf of Maine. We accepted their value. Less information is available about the nutrient concentrations in these waters. We compared salinities and concentrations of TIN and phosphate of the 1975 and 1976 NODC data from the north-east channel with our summertime data off of Yarmouth (Nova Scotia). In the upper $50 \mathrm{~m}$, the north-east channel data and our data were remarkably similar, suggesting that the waters flowing into 
the Gulf across the Scotian Shelf and through the surface of the north-east channel both represented Scotian Shelf water. In the upper $50 \mathrm{~m}$ in summer, these waters had salinities of about $32.0 \mathrm{~g} \mathrm{~kg}^{1}$, nitrate + nitrite concentrations of about $3 \mu$ gat $\mathrm{N}^{-1}$ and phosphate concentrations of about $0.3 \mu$ gat $\mathrm{P}^{-1}$. Again, we failed to find consistent evidence of high ammonium concentrations in our data or in other unpublished data sets. During most of the year when vertically stratified waters occur, nutrient and salinity concentrations increased with depth. Thus, waters deeper than $50 \mathrm{~m}$ entering from the Scotian Shclf contained significantly greater salinities and nutrient concentrations. Also, average concentrations were higher in the winter months (Fig. 8). Thus, we used an average salinity, IIN and $\mathrm{PO}_{4}$ concentrations of $32.4 \mathrm{~g} \mathrm{~kg}^{-1} 5.0 \mu$ gat $\mathrm{N}^{-1}$ and $0.40 \mu \mathrm{gat} \mathrm{P} \mathrm{I}{ }^{1}$, respectively. The resulting total inflows from the Scotian Shelf were $6.480 \times 10^{6}\left(\mathrm{~g} \mathrm{~kg}^{-1}\right)$ $\left(\mathrm{m}^{3} \mathrm{~s}^{-1}\right)$ of salt, $2.52 \times 10^{9}$ gat $\mathrm{P} \mathrm{y}^{-1}$ of phosphate, and $31.5 \times 10^{9}$ gat $\mathrm{N} \mathrm{y}^{-1}$ of TIN (Table 1).

Total inflows into the Gulf were the sum of that from the north-east channel, across the Scotian Shelf, and due to river and wet precipitation minus evaporation. Input of water via rivers and wet precipitation minus evaporation was taken to be $4000 \mathrm{~m}^{3} \mathrm{~s}^{-1}$ (Brown and Beardsley, 1978) with no significant salt content, the same nitrogen content used by Schlitz and Cohen (1984), and a nominal phosphate concentration of $0.5 \mu$ gat $\mathrm{PI}^{-1}$. Thus, in total for the Gulf, the inflow of water was $466,000 \mathrm{~m}^{3} \mathrm{~s}^{-1}$, salt was $15.267 \times 10^{6}\left(\mathrm{~g} \mathrm{~kg}^{\mathrm{l}}\right)$ $\left(\mathrm{m}^{3} \mathrm{~s}^{-1}\right)$, phosphate was $8.69 \times 10^{9}$ gat $\mathrm{P} \mathrm{y}^{-1}$, and TIN was $138.6 \times 10^{4}$ gat $\mathrm{N} \mathrm{y}^{-1}$ (Table 1).

Both Schlitz and Cohen (1984) and Brown and Beardsley (1978) selected the waters leaving the Gulf as the westward flowing current located south of Cape Cod on the New England Shelf. Although this is the general circulation pattern, the flow on the New England Shelf appears more complex. Brown and Beardsley (1978) noted the occurrence of significant "calving" of the westward flowing shelf current with the offshore slope waters in the region south and west of Gcorges Bank. Coupled to this across-shelf mixing, Bumpus (1973) showed that there was a consistent onshore flow extending across the shelf in the region south of Capc Cod. The extent to which cross-shelf exchange may alter salinitics and nutrient concentrations of the New England Shelf current are unknown. Schlitz and Cohen (1984) presented an average nitrate + nitrite concentration of these waters in springtime $\left(1.7 \mu\right.$ gat $\left.\mathrm{N}^{-1}\right)$ which were significantly less than we found in our exiting waters. Pastuszak et al. (1982) also noted nitrate concentrations on Gcorges Bank which were lower than those in our exiting waters.

We characterized the waters which must exit the Gulf as those found just east of Cape Cod. These waters are at the end of the alongshore current that flows south-west adjacent to the coasts of Maine, New Hampshire, and eastern Massachusetts and as such represent the end result of the processes of mixing, air/sea cxchange, river inputs and biological cycling that influence sea watcr composition within the Gulf. Thus, we feel that the use of data from the southern part of the Gulf better represents the exiting waters than does data from the New England Shelf. Based on NODC data from the region between 42.4 and $41.0^{\circ} \mathrm{N}$ and between 69 and $70^{\circ} \mathrm{W}$ longitude, vertical profiles of salinity, nitrate + nitrite, and phosphate were integrated over the upper $100 \mathrm{~m}$ to obtain the salt, nitrate + nitrite, and phosphate inventory. (Integration used extrapolation without change of the shallowest data to the sea surface, linear interpolation between measured data and trapezoidal integration.) Depth-averaged data arc presented vs the Julian day of sampling (Fig. 9). We have taken the NODC nitrate + nitrite concentrations as equal to the TIN content, and 

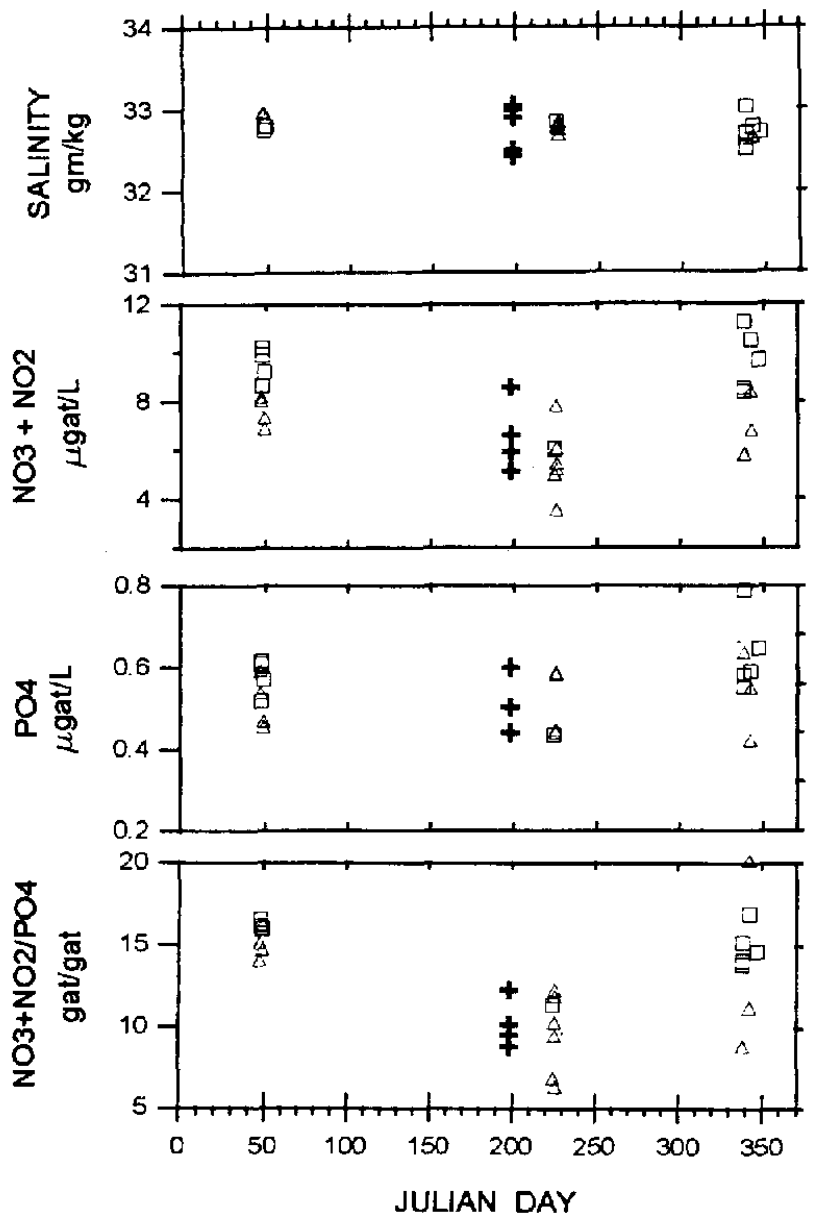

Fig. 9. Average salinity, nitrate + nitrite, phosphate, and the ratio of nitrate plus nitrite to phosphate in the upper $100 \mathrm{~m}$ of the waters east of Cape Cod vs Julian Day. Open squares represent all NODC data from 1975 and 1976 between $69^{\circ} \mathrm{W}$ and $70^{\circ} \mathrm{W}$ and between 41.0 and $42.4^{\circ} \mathrm{N}$. Open triangles represent all stations from the same data set between 68 and $69^{\circ} \mathrm{W}$. Crosses represent our Stas 1-5 from transect 1 .

this data agrees with that from our southernmost transect (Fig. 9). Exiting waters had average salinities of $32.75 \mathrm{~g} \mathrm{~kg}^{-1}$, nitrate + nitrite concentrations of $7.9 \mu$ gat N $~^{-1}$ and a phosphate content of $0.55 \mu$ gat $\mathbf{P ~ I}^{1}$. A part of these waters flows south and joins the westward alongshelf flow on the New England Shelf, thus exiting the Gulf relatively rapidly. However, a part may also be entrained in the counter-clockwise gyre over Georges Bank. In this case, these waters may be exposed to continual nutrient loss through burial, through organic matter export, or through sedimentary denitrification. In the following paragraphs, we will estimate burial independently, and both burial and organic matter export rates will be shown to be small. Sedimentary denitrification would lower the nitrogen content of these waters as they pass through the Georges Bank area before exiting along the New England Shelf. Thus, using the waters east of Cape Cod as the cxiting 
waters would overestimate the nitrogen content of the exiting waters but would have little affect on phosphate concentrations and salinity. These tendencies seem supported by the following observations. The NODC data from the same latitudes but $1^{\circ}$ longitude to the east $\left(68-69^{\circ} \mathrm{W}\right)$ showed essentially the same average salinities and phosphate concentrations in the upper $100 \mathrm{~m}$ but lower concentrations of nitrate + nitrite $\left(6.5 \mu \mathrm{gat} \mathrm{N} \mathrm{I}^{-1}\right)$. Also, Pastuszak et al. (1982) found considerably lower nitratc concentrations (0.3-6.6 $\mu$ gat $\mathrm{N}^{-1}$ ) on Georges Bank.

The outflow of dissolved constituents can now be estimated based on a balanced water flow. For salinity, the outflow totals $15.262 \times 10^{6}\left(\mathrm{~g} \mathrm{~kg}^{1}\right)\left(\mathrm{m}^{3} \mathrm{~s}^{1}\right)$, and advective removal of phosphate was $8.08 \times 10^{9}$ gat $\mathrm{P}_{\mathrm{y}}{ }^{1}$. Using an exiting TIN content of $6.5 \mu$ gat $\mathrm{N}^{-1}$, the TIN outflow would be $95.5 \times 10^{9}$ gat $\mathrm{N} \mathrm{y}^{-1}$. For salinity, the budget balances within 0.005 $\times 10^{6}\left(\mathrm{~g} \mathrm{~kg}^{-1}\right)\left(\mathrm{m}^{3} \mathrm{~s}^{-1}\right)$ which is equivalent to an underestimation of the salinity of exiting waters by $0.011 \mathrm{~g} \mathrm{~kg}^{-1}$. For phosphate and TIN, inflows exceed outflows by $0.61 \times 10^{9}$ gat $\mathrm{P}^{-1}$ and $43.1 \times 10^{9}$ gat $\mathrm{N} \mathrm{y}^{-1}$.

The likely loss terms for both nitrogen and phosphate would include long term burial in sediments, fishing and other anthropogenic harvesting, and advective export of some fraction of primary production as organic matter (Christensen, 1989; Christensen et al., 1992). Burial of organic carbon was estimated by Christensen (1989) as $5.0 \mathrm{~g} \mathrm{C} \mathrm{m}^{-2} \mathrm{y}^{-1}$ based on an average carbon content in sediments of $1.0 \% \mathrm{w} / \mathrm{w}$. With a $\mathrm{C} / \mathrm{N}$ weight ratio of 10:1 for these sediments, organic nitrogen burial would amount to $-4.4 \times 10^{9} \mathrm{gat} \mathrm{N} \mathrm{y}^{-1}$. With a C/P atomic ratio of 250 (Froelich et al., 1982), organic phosphate burial would amount to $-0.21 \times 10^{9}$ gat $\mathrm{P} \mathrm{y}^{-1}$. Burial of phosphate bound in calcium carbonate would add an additional $-0.05 \times 10^{9}$ gat $\mathrm{P} \mathrm{y}^{-1}$ assuming an average carbonate w/w content in sediments of $1 \%$ and an inorganic atomic C/P ratio of 1000 (Froclich et al., 1982). Total phosphate burial would then be $-0.26 \times 10^{9}$ gat $\mathrm{P} \mathrm{y}^{-1}$. Fishing and other harvesting were negligible in the overall nitrogen budget (Christensen et al., 1992). At this point, the phosphatc balance based on water advection and burial shows a net input of only $0.35 \times$ $10^{9}$ gat $\mathrm{P} \mathrm{y}^{-1}, 4 \%$ of the total inputs. A mathematical balance would require exiting waters to have $0.024 \mu$ gat $1^{-1}$ more $\mathrm{P}$ than listed in Table 1 . Thus, the phosphate budget is essentially balanced with little need for additional losses. However, an ecosystem model built by Campbell (1986) shows that export of phytoplankton and zooplankton could account for roughly $10 \%$ of the net inorganic nitrogen input to the Gulf of Maine. Independently, Christensen (1989) compared the sum of the carbon oxidation and hurial rates within Gulf of Maine sediments with the expected flux of organic matter to the sediments. The latter flux was calculated from surface primary productivity and its relationship to sinking fluxes of organic material as estimated from the relationships of Betzer et al. (1984) and of Suess (1980). For the Gulf of Maine, the expected inputs of organic carbon closely matched the sedimentary oxidation and burial rates. This vertical balance can only occur if lateral inputs and losses of organic matter to or from the Gulf are small relative to the existing productivity and its vertical flux. Thus, Christensen (1989) concluded that export of organic matter must be less than the uncertainty either in the average productivity or in the sediment metabolism rates (both about $\pm 15 \%$ ). Export of $1.5 \%$ of the productivity from the Gulf of Maine, as listed in Schlitz and Cohen (1984), would account for $5.6 \times 10^{9}$ gat $\mathrm{N} \mathrm{y}^{-1}$ and $0.35 \times 10^{9}$ gat $\mathrm{P} \mathrm{y}^{1}$, and this would exactly balance the phosphate budget.

Denitrification based on globally realistic rates could easily account for the remainder of the missing nitrogen. Christensen $e t$ al. (1987) conservatively estimated the total denitrifi- 
cation on continental shelf sediments to be $50 \times 10^{12} \mathrm{~g} \mathrm{~N} \mathrm{y}^{-1}$, or 0.41 pgat $\mathrm{N} \mathrm{cm}^{-2} \mathrm{~s}^{-1}$ when averaged over the global shelf area. More recently, high rates found in estuaries (Seitzinger, 1988) and on other continental shelves (Devol, 1991; Devol and Christensen, 1993) would result in an appreciable increase in both the contribution of coastal areas to global nitrogen loss and in the expected loss rate for the Gulf of Maine. New measurements in the Gulf of Maine (Christensen, in preparation) showed rates that ranged from 0.25 pgat $\mathrm{N} \mathrm{cm}^{-2} \mathrm{~s}^{-1}$ in the deeper Jordan Basin to $>4$ pgat $\mathrm{N} \mathrm{cm}^{-2} \mathrm{~s}^{-1}$ in shallower sites. An average rate of 0.85 pgat $\mathrm{N} \mathrm{cm}^{-2} \mathrm{~s}^{1}$ would balance our nitrogen budget for the Gulf of Maine, removing $33.1 \times 10^{9}$ gat $\mathrm{N} \mathrm{y}^{-1}$ (Table 1). This would account for $77 \%$ of the missing nitrogen and $24 \%$ of all nitrogen inputs. The denitrification rate estimated from this budget agrees with that estimated from the residence time calculation.

The above discussion shows that the missing nitrogen of the Gulf's inorganic nitrogen budget can be easily explained based on burial and export of a small amount of the Gulf's productivity (11\% and $12 \%$ of the missing nitrogen, respectively) and by denitrification ( $77 \%$ of the missing nitrogen). The nitrogen budget indicates that denitrification may remove $24 \%$ of the nitrogen input to the Gulf of Maine, and our analysis of the summertime nutrient distribution showed a removal of $2-4 \mu$ gat $\mathrm{N} \mathrm{I}^{-1}$ relative to phosphate or silicate. In this regard, denitrification is a major nitrogen sink and so it competes with primary producers for the overall supply of combined nitrogen. For example, an increase in the role of denitrification relative to inputs would result in decreased nutrient concentrations and to a likely decrease in productivity. Either largescale anthropogenic impacts to coastal waters or climatic alterations of the water budget could possibly alter the rate of denitrification and its relative role in the nitrogen budget of this coastal sea. Thus, the productivity of the Gulf of Maine may be sensitive to possible environmental or climatological changes.

Acknowledgements-This report was supported primarily by NSF grant No. OCE-9103384 to Christensen. Christensen also thanks the Chemistry Department at Bowdoin College for their support. 'This is contribution No. 94005 from Bigelow Laboratory for Ocean Sciences, and No. 9401 from the Department of Oceanography at the University of Maine.

\section{REFERENCES}

Aminot A. and R. Kerouel (1982) Dosage automatique de l'uree dans l'eau de mer: unc methode tres sensible a la diacetylmonoxime. Canadian Journal of Fisheries and Aquatic Science, 39, 174-183.

Bctzer P. R., W. J. Showers, E. A. Laws, C. D. Winn, G. R. Ditullio and P. M. Kroopnick (1984) Primary productivity and particle fluxes on a transect of the equator at $153^{\circ} \mathrm{W}$ in the Pacific Ocean. Deep-Sea Research, 31, 1-11.

Bigelow H. B. (1927) Physical oceanography of the Gull of Mainc. Bulletin of the United States Bureau of Fisheries, 40, 511-1027.

Bigelow H. B., L. C. Lillick and M. Sears (1940) Phytoplankton and planktonic protozoa of the offshore waters of the Gulf of Maine. Part 1. Numerical distribution. Transactions of the American Philosophical Society, 31, 149-191.

Brooks D. A. (1985) Vernal circulation in the Gulf of Mainc. Journal of Geophysical Research, 90, 4687-4705.

Brooks D. A. (1987) The influence of warm-core rings on slope water entering the Gulf of Maine. Journal of Geophysical Research, 92, 8183-8196.

Brooks D. A. and D. W. Townsend (1989) Variability of the coastal current and nutrient pathways in the eastern Gulf of Maine. Journal of Marine Research, 47, 303-321.

Brown W. S. and R. C. Beardsley (1978) Winter circulation in the Western Gulf of Maine: Part 1. Cooling and water mass formation. Journal of Physical Oceanogruphy, 8, 265-277. 
Bumpus D. F. (1973) A description of the circulation on the continental shelf of the east coast of the Unitcd States. In: Progress in oceanography, vol 6, B. A. Warren, editor, Pergamon Press, NY, pp. 111-157.

Burgess T. M. and R. Webster (1980) Optimal interpolation and isarithmic mapping of soil properties. II. Block kriging. Journal of Soil Science, 31, 333-341.

Butman B. and R. C. Beardsley (1987) Physical oceanography. In: Georges Bank, R. H. Backus and D. W. Bourne, editors, MIT Press, Cambridge, Massachusetts, pp. 88-98.

Butman B., R. C. Beardsley, B. Magnell, D. Frye, J. A. Vermersch, R. Schlitz, R. Limeburmer, W. R. Wright and M. A. Noble (1982) Recent observations of the mean circulation on Georges Bank. Journal of Physical Oceanography, 12, 569-591.

Campbell D. E. (1986) Process variability in the Gulf of Maine-a macroestuarine environment. In: Estuarine variability, D. A. Wolfe, editor, Academic Press, New York, pp. 261-275.

Christensen J. P. (1989) Sulfate reduction and carbon oxidation in continental shelf sediments, an examination of of rshelf carbon transport. Continental Shelf Research, 9, 223-246.

Christensen J. P., J. W. Murray, A. H. Devol and L. A. Codispoti (1987) Denitrification in continental shelf sediments has major impact on the oceanic nitrogen budget. Global Biogeochemical Cycles, 1, 97-116.

Christensen J. P., D. B. Smith and L. M. Mayer (1992) 'l'he nitrogen budget of the Gulf of Mainc and climate change. In: Proceedings of the Gulf of Maine scientific workshop, J. Wiggin and N. K. Mooers, editors, Urhan Harbor Institute of the University of Massachusetts at Boston, pp. 75-90.

Codispoti L. A. (1989) Phosphorus vs nitrogen limitation of new and export production. In: Productivity of the Ocean: Present and Past, W. H. Berger, V. S. Smctacek and G. Wefer, editors, Wiley-Interscience, NY, pp. $377-394$.

Cura J. J. Jr (1987) Phytoplankton. In: Georges Bank, R. H. Backus and D. W. Bourne, editors, MIT Press, Cambridge, Massachusetts, pp. 213-218.

Devol A. H. (1991) Direct mcasurements of nitrogen gas fluxes from continental shelf sediments. Nature, 349, $319-321$.

Devol A. H. and J. P. Christensen (1993) Benthic fluxes and nitrogen cycling in sediments of the continental margin of the eastern North Pacific. Journal of Marine Research, 51, 345-372.

Drinkwater K., B. Pctric and W. H. Sutcliffe, Jr. (1979) Seasonal geostrophic volume transports along the Scotian Shelf. Estuarine and Coastal Marine Science, 9, 17-27.

Froelich P. N., M. I. Bender, N. A. Luedtke, G. R. Heath and T. Devries (1982) The marine phosphorus cycle. American Journal of Science, 282, 474-511.

Hopkins T. S. and N. Garficld III (1979) Gulf of Maine intermediate waters. Journal of Marine Research, 37, 103-139.

Kemp W. M., P. Sampou, J. Caffrey and M. Mayer (1990) Ammonium recycling versus denitrification in Chesapeake Bay sediments. Limnology and Oceanography, 35, 1545-1563.

I.illick I. C. (1940) Phytoplankton and planktonic protozoa of the offshore waters of the Gulf of Mainc. Transactions of the American Philosophical Society, 31, 193-237.

Minster J. F. and M. Boulahdid (1987) Redfield ratios along isopycnal surfaces-a complementary study. Deep-Sea Research, 34, 1981-2003.

O'Rcilly J. E. and D. A. Busch (1984) Phytoplankton primary production on the northwest Atlantic shelf. Rapports et Proces-verhaux des Reunions. Cunseil International pour l'Exploration de la Mer, 183, $255-268$.

Pastuszak M., W. R. Wright and D. Patanjo (1982) One year of nutrient distribution in the Georges Bank region in relation to hydrography, 1975-1976. Journal of Marine Research, 40 (suppl.), 525-542.

Ramp S. R., R. J. Schlitz and W. R. Wright (1985) The deep flow through the northeast channel, Gulf of Maine. Journal of Physical Oceunography, 15, 1790-1808.

Schlitz R. J. and E. B. Cohen (1984) A nitrogen budget for the Gulf of Maine and Georges Bank. Biological Oceanography, 3, 203-222.

Seitzinger S. P. (1988) Denitrification in freshwater and coastal marine ecosystems: ccological and geochemical significance. Limnology and Oceanography, 33, 702-724.

Smith C. I., R. D. Delaune and W. H. Patrick Jr (1985) Fate of riverine nitrate entering an estuary: I. Denitrification and nitrogen burial. Estuaries, 8, 15-21.

Strickland J. D. H. and T. R. Parsons (1972) A practical handbook of scawater analysis, 2nd edn. Bulletin of the Fisheries Research Board of Canada, 167, 1-310.

Suess E. (1980) Particulate organic carbon flux in the oceans-surface productivity and oxygen utilization. Nature, 288, 260-263. 
Sutcliffe W. H. Jr, R. H. Loucks and K. F. Drinkwater (1976) Coastal circulation and physical oceanography of the Scotian Shelf and the Gulf of Maine. Journal of the Fisheries Research Board of Canada, 33, 98-115.

Takahashi T., W. S. Broecker and S. Langer (1985) Redfield ratio based on chemical data from isopycnal surfaces. Journal of Geophysical Research, 90, 6907-6924.

Townsend D. W. (1991) Influences of oceanographic processes on the biological productivity of the Gulf of Maine. Reviews in Aquatic Sciences, 5, 311-230.

Townsend D. W. and J. P. Christensen (1986) Summertine oceanographic conditions in the Gulf of Maine, 1624 July 1985: physical oceanographic, nutrient, and chlorophyll data. Technical Report No. 61, Bigelow Laboratory for Ocean Sciences, West Boothbay Harbor, Maine, U.S. A., 422 pp.

Townsend D. W. , J. P. Christensen, D. K. Stevenson, J. J. Graham and S. B. Chenoweth (1987) The importance of a plume of tidally-mixed water to the biological oceanography of the Gulf of Maine. Journal of Marine Research, 45, 699-728.

Townsend D. W., M. D. Keller, M. E. Sieracki and S. G. Ackleson (1992) Spring phytoplankton blooms in the absence of vertical water column stratification. Nature, 360, 59-62. 